\title{
Nový nález pozdně středověkého dlouhého meče ze Ždánického lesa
}

\author{
A new find of a late medieval long-sword from Ždánice Forest
}

- Petr Žákovský*, Patrick Bárta, Jiř́i Hošek, Klára Rybářová-

\section{KEYWORDS:}

Long-sword - Middle Ages - Moravia - Ždánice Forest

\section{ABSTRACT}

In 2019, a metal-detector find of an exceptionally well-preserved weapon was made in the complex of Ždánice Forest. We can classify it as a long-sword of Type XVIa, H1, $1 \mathrm{~b}$ (according to Oakeshott 1964; Gtosek 1984, 39-40, Fig. 4) and date it to the turn of the $15^{\text {th }}$ century. Its blade was marked on both sides with three marks taking the form of a forked cross, a diagonal consisting of three equilateral crosses and, finally, a bishop's crosier. The weapon was assembled from a blade of Passau provenance and hilt-components characteristic of the wider Central European region. These and other facts concerning the sword were obtained through detailed analysis, which this study introduces.

\section{* Corresponding author - E-mail address: zakovsky@arub.cz}

\section{Úvod}

Zalesněná oblast přírodního parku Ždánický les nepatří k zajímavým oblastem pouze z hlediska turistiky a přírodního bohatství, nýbrž je bohatá i na památky archeologické. V posledních 20-30 letech je nárůst kovových archeologických nálezů z daného prostoru poměrně enormní, což je úzce spjato s masivním používáním detekční techniky k vyhledávání metalických artefaktů. To má pro archeologii z pochopitelných důvodů celou řadu negativních důsledků. Souvisejí především s obrovským rozsahem ztrát archeologického materiálu a s ním organicky spjatých informací. Přesto nelze této aktivitě upřít i jisté pozitivní konsekvence. Jednou z nich je možnost masivního zapojení poučených spolupracovníků do průzkumů určitých zájmových regionů, s nímž jde ruku v ruce i nebývalý nárůst archeologických nálezů z těchto oblastí, které by byly tradičními archeologickými metodami jen stěží postižitelné. Tyto nálezy totiž zpravidla nejsou vázány na žádné výraznější archeologické lokality či situace, nebot̉ se povětšinou jedná o někdejší náhodné ztráty v rámci cestování, loveckých aktivit apod., přičemž o př́ičině jejich archeologizace se můžeme jen dohadovat. Proto se tyto nálezy většinou soustřed'ují v blízkosti komunikací, at již zaniklých či stále využívaných, popř́ípadě v lesních komplexech, které od středověku nebyly výrazněji kultivovány a neproběhly v nich zásadnější krajinné transformace.

Na území jižní Moravy se tato situace, mimo oblast Př́rodního parku Bobrava mezi Rosicemi a Střelicemi a rozsáhlý komplex Krumlovského lesa, týká ve zvýšené míře právě oblasti Ždánického lesa a na něj navazující vrchoviny Chřiby. Z této oblasti pochází značné množství archeologických nálezů, mezi nimiž zaujímají nezanedbatelnou pozici i různé druhy a typy středověkých a raně novověkých militarií. V roce 2019 byl v této oblasti nalezen i výjimečně dobře dochovaný dlouhý meč, který již nemohl být zahrnut do nedávno publikovaného souborného díla o středověkých a raně novověkých mečích z území České republiky (Hošek et al. 2019; 2020), a je mu proto věnována tato krátká studie.

\section{Nálezové okolnosti}

Meč byl nalezen spolupracovníkem Muzea Vyškovska pomocí detektoru kovů na zalesněném východním svahu v poloze „U široké cesty“ na katastru Mouř́nova. Zbraň byla nálezcem jen částečně odkryta a k jejímu odbornému vyzvednutí byla přivolána archeoložka vyškovského muzea. Na základě odborného, standardním zpo̊sobem provedeného vyzvednutí lze konstatovat, že zbraň byla uložena v hloubce cca $20 \mathrm{~cm}$ od současné nivelety. Zbraň byla odkryta ve středně ulehlé žlutošedé jílovité půdě (hloubka cca $6 \mathrm{~cm}$ ), nad níž se nacházela $14 \mathrm{~cm}$ mocná hnědá sypká humózní vrstva. Žádné stopy po záměrném vkopu, 
který by mohl naznačovat úmyslné uložení meče do země, zjištěny nebyly. Následnou systematickou prospekcí v bezprostředním okolí nálezu se také nepodařilo získat žádné další artefakty, které by se studovanou zbraní mohly souviset (obr. 1).

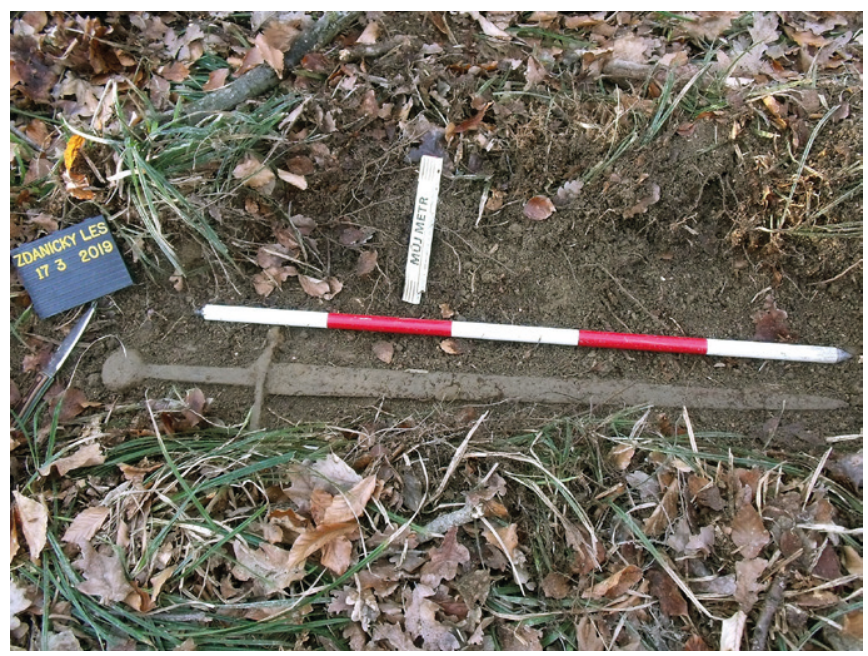

Obr. 1. Nálezová situace meče po jeho částečném vypreparování. Foto K. Rybářová. Fig. 1. Archaeological context of the partially uncovered sword. Photo by K. Rybářová.

\section{Popis meče}

Jedná se o velmi dobře zachovalý masivní dlouhý meč o celkové délce $1150 \mathrm{~mm}$, jehož hmotnost před konzervací dosahovala 2044 g a po konzervaci provedené v laboratořích Archeologického ústavu AV ČR, Brno pak 1905 g. Těžiště zbraně bylo naměřeno na čepeli ve vzdálenosti zhruba $75 \mathrm{~mm}$ od spodní hrany záštity. Jelikož zbraň byla ke konzervaci předána v nálezovém stavu, lze s jistotou říci, že v korozních produktech se nezachovaly žádné organické zbytky obložení rukojeti či pochvy a nebylo zjištěno ani zdobení garnitury rukojeti zbraně aplikacemi z neželezných kovů (obr. 2-4).

Zbraň je vybavena $888 \mathrm{~mm}$ dlouhou, poměrně masivní obousečnou čepelí, jejíz šířka se směrem k hrotu plynule parabolicky zužuje z $53 \mathrm{~mm}$ u záštity až na $20 \mathrm{~mm}$ naměřených před začátkem hrotové partie. Vlastní hrot je poměrně výrazný. Tloušt'ka čepele se směrem $\mathrm{k}$ hrotu plynule zužuje z původních 7 na $3 \mathrm{~mm}$. Čepel je po obou stranách opatřena poměrně mělkým, nevýrazně ohraničeným a téměř $1 / 3$ šířky čepele zabírajícím žlábkem, který začíná na řapu a končí zhruba $310 \mathrm{~mm}$ od hrotu. Při rentgenografickém průzkumu byly po obou stranách čepele objeveny série trojic drobných značek, sestávajících z vidlicového kříže těsně pod záštitou, kterou zhruba v polovině hrubí doprovází diagonála, tvořená trojicí malých rovnoramenných kř́ižků. Pod ukončením žlábků je pak čepel po obou svých plochách značena i poměrně rozměrnou značkou v podobě biskupské berly. Původně byly nejspíš značky vyplněny neželezným kovem, jak o tom svědčí malý zbytek žlutého kovu v jednom z křrižků jedné z diagonál.

Na čepel navazuje oboustranně odsazený řap o délce $262 \mathrm{~mm}$, jehož šířka se směrem k hlavici plynule parabolicky zužuje z původních $31 \mathrm{~mm}$, naměřených u svrchní hrany záštity, až na $24 \mathrm{~mm}$ pod spodní hranou hlavice. Tloušťka řapu je po celou jeho měřitelnou délku takřka konstantní a kolísá kolem $7 \mathrm{~mm}$. Ve spodní části řapu jsou po obou jeho plochách zřetelné počátky žlábku čepele. Po odečtení šiřrky ecussonu $(11 \mathrm{~mm})$ a délky hlavice $(63 \mathrm{~mm})$ od celkové délky řapu $(262 \mathrm{~mm})$ dostaneme celkovou délku původní rukojeti $188 \mathrm{~mm}$.

Záštita délky 243 mm má k čepeli mírně prohnutá ramena, vyrobená z hraněné železné tyčinky přibližně kvadratického, místy až obdélného průřezu. Jejich šiřka i tloušťka se směrem od nevýrazně vyvinutého ecussonu plynule zužuje z 11 na $9 \mathrm{~mm}$, maximální tloušťka ecussonu dosahuje $11 \mathrm{~mm}$. Konce ramen záštity jsou specificky zahnuty vzhůru směrem k hlavici zbraně. Jedno z ramen vykazuje mírnou deformaci, způsobenou patrně nasazením záštity na asymetricky odsazený řap, nebot záštita byla na řap nejspíše naražena zatepla, čímž došlo k jejímu usazení.

Meč je vybaven masivní, poměrně plochou hlavicí oválného tvaru s výrazně zkosenými, místy až konkávními hranami, respektive bočními stěnami. Její maximální délka dosahuje $63 \mathrm{~mm}$, maximální šířka $75 \mathrm{~mm}$. Tloušťka hlavice dosahuje max. $30 \mathrm{~mm}$, u svrchní i spodní hrany pak 23 mm. Násadní kónický otvor procházející celou hlavicí je na spodní ploše zvětšen oproti rozměrům řapu a má čtvercový půdorys. Na svrchní ploše hlavice jsou patrné zbytky roznýtovaného konce řapu, formovaného do tvaru nízkého komolého jehlanu.

\section{Chronologicko-typologická analýza meče}

\section{Čepel}

Meč je vybaven značně masivní obousečnou, plynule se zužující čepelí plochého až mírně hexagonálního průřezu, s výrazným hrotem a poměrně mělkým a nevýrazně ohraničeným žlábkem, ukončeným zhruba ve dvou třetinách její celkové délky. Těmito základními charakteristikami odpovídá jednoznačně čepelím typu XVIa (Oakeshott 1964, 63), od kterých se mírně odlišuje pouze délkou svého žlábku. Pro daný typ jsou totiž příznačné spíše žlábky kratších délek, nedosahující ani poloviny

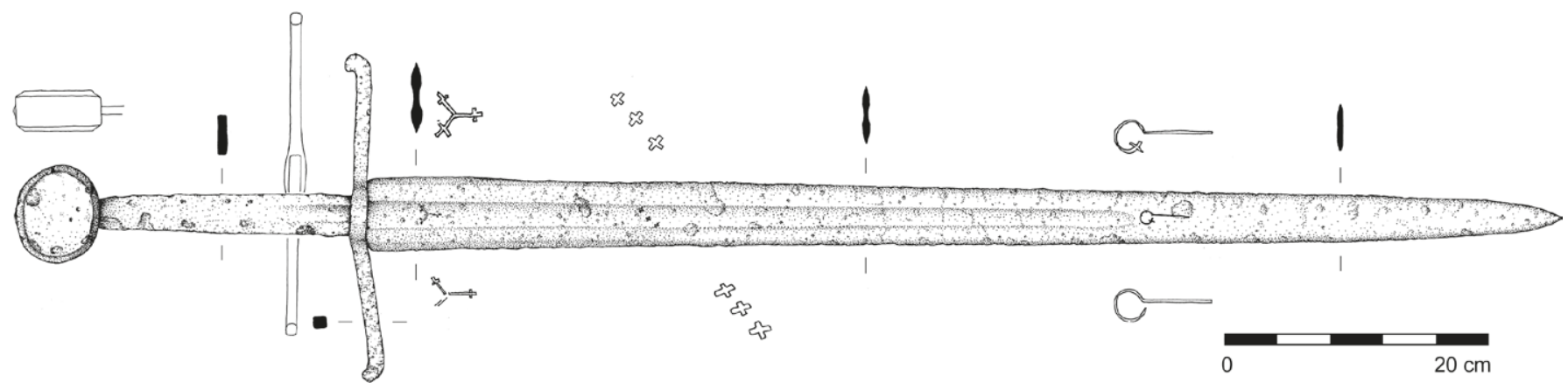

Obr. 2. Meč z Mouřínova. Kresba P. Žákovský.

Fig. 2. The Mouřínov sword. Drawing by P. Žákovský. 


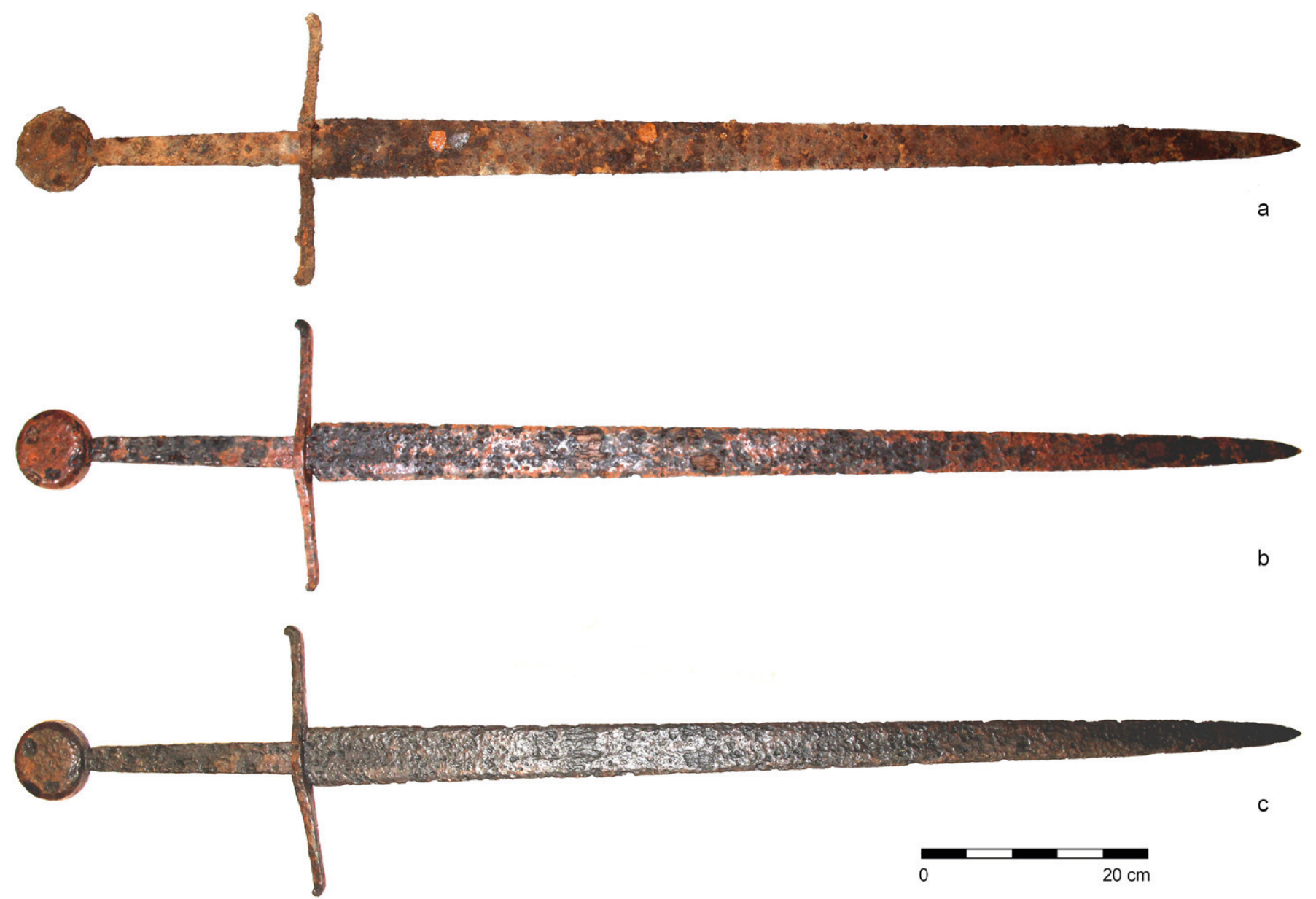

Obr. 3. Meč z Mouřínova: a - zbraň v nálezovém stavu; b - zbraň po mechanickém očištění a desalinaci před závěrečnou povrchovou úpravou; c - stav zbraně po skončeném konzervačním zásahu. Foto P. Žákovský.

Fig. 3. The Mouřínov sword: a - the weapon in as-excavated condition; b-when mechanically cleaned and desalinated before final surface treatment; c - after conservation. Photo by P. Žákovský.

celkových délek čepelí, byt๋ v ojedinělých př́ípadech mohou tuto mez překračovat (např. Oakeshott 1964, 63). Pro tyto čepele dlouhých mečů jsou dále typické dlouhé řapy určené k obouručnímu úchopu, v jejichž spodní části jsou často zřetelné počátky žlábků, jak je to ostatně patrné i na námi zkoumaném nálezu.

Čepele typu XVIa nepochybně vycházejí z čepelí dlouhých mečů typu XIIIa, se kterými byly částečně současné, ale charakteristické jsou zejména pro závěr 14. a počátek 15. století. Od poměrně plochých čepelí dlouhých mečů typu XIIIa se neodlišují pouze svým výrazným zahrocením, ale především svým více či méně výrazným hexagonálním průřezem, který čepelím typu XVIa zabezpečoval větší tuhost a částečně tak zabraňoval nežádoucímu bočnímu prohybu čepele při dobodnutí do tvrdé překážky. Společně s čepelemi výrazně hexagonálního průřezu typu XVII tak představovaly jakýsi pomyslný přechodový článek mezi obecně běžnými plochými čepelemi typu XIIIa, rozšířenými zejména v průběhu 14. století, a vesměs výrazně zahrocenými čepelemi rombického průřezu, typickými pro průběh století následujícího. Obecně se dá soudit, že u čepelí studovaného typu, respektive u jejich tvarové modifikace a změně průřezu, by se mohlo jednat o přímý důsledek snahy výrobců mečů reagovat na dynamicky vyvíjející se plátovou zbroj v posledních desetiletích 14. století (srov. Gamber 1953; Blair 1958, 53-76; Žákovský 2009b, 413-424; Capwell 2015, 113-150). Je však nutné přiznat, že čepele typu XVIa se uplatnily při konstrukci dlouhých mečů patrně již v průběhu 1. poloviny 14. století, byt jen zcela ojediněle (např. Oakeshott 1964, 63-65).

Obecně tento typ patří k jednomu z nejpoužívanějších tvarů čepelí v období vrcholného středověku vůbec. V rámci soupisu mečů z oblasti střední Evropy klasifikoval M. Głosek typem XVIa celkem 131 čepelí dlouhých mečů, což je v dané oblasti

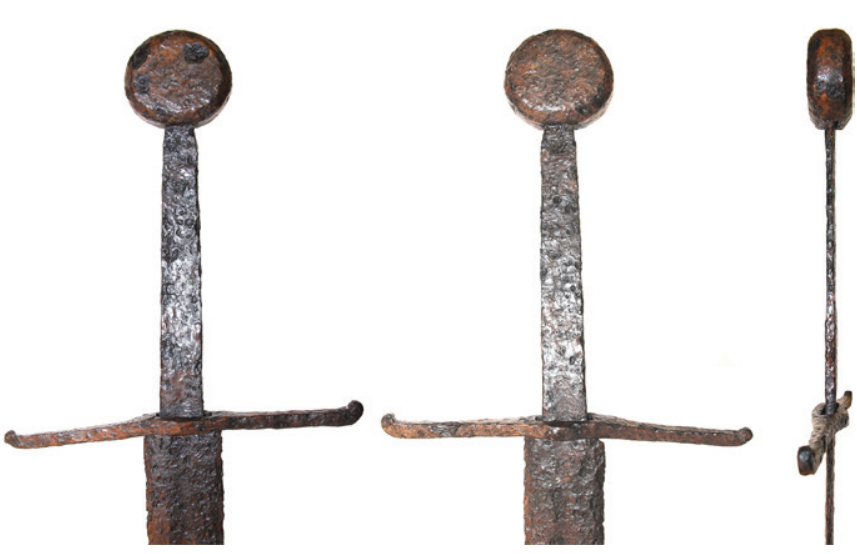

Obr. 4. Meč z Mouřínova - detail garnitury rukojeti. Foto P. Žákovský.

Fig. 4. The Mouř́nov sword - detail of the hilt components. Photo by P. Žákovský. 
zařadilo bezkonkurenčně na první místo v pomyslném žebř́čcku výskytu (Glosek 1984, 29). Obdobnou situaci lze konstatovat rovněž v oblasti jihovýchodní Evropy, kde čepele typu XVIa a XIIIa patř́ společně $\mathrm{k}$ jasně dominujícím typům, přičemž typem XVIa bylo v dané oblasti M. Aleksićem klasifikováno celkem 70 čepelí dlouhých mečů (Aleksić 2007, 89). Pokud se podíváme v této souvislosti na situaci na území České republiky, lze konstatovat, že i zde čepele sledovaného typu představují jeden z nejrozšířenějších tvarů čepelí. Z celkového dosud podchyceného počtu 238 mečů a jejich blíže klasifikovatelných zlomků, datovatelných do průběhu 2. poloviny 13. - 1. poloviny 16. století, z našeho území představují meče s čepelemi typu XVIa celkem 56 více či méně určitelných exemplářů, tedy celkem $23,5 \%$ (Hošek et al. 2020). Je však nutné vzít v potaz jistou subjektivitu při řazení konkrétních exemplářů do jednotlivých typů, nebot? čepele daného typu lze $\mathrm{v}$ určitých případech snadno zaměnit za čepele typů XIIa a u neúplných čepelí dokonce za typ XVII. I s vědomím těchto limitů však lze prohlásit, že čepele typu XVIa i v českém a moravském materiálu dominují.

\section{Hlavice}

Čepele typu XVIa jsou kombinovány především s garniturami rukojetí, při jejichž konstrukci se uplatnily zejména různé varianty hlavic kruhového tvaru typu $J$ a $K$ či hlavic oválných forem typu H1. To ostatně potvrzuje i dlouhý meč z Mouřínova, který je vybaven typickým představitelem poměrně masivních plochých, mírně oválných hlavic typu $H 1$ s výrazně zkosenými, místy až konkávními hranami, respektive bočními stěnami, které výrazně vymezují centrální disky hlavice. Obdobné tvary představují jeden z nejběžnějších typů hlavic dlouhých mečů z průběhu 2. poloviny 14. a 1. poloviny 15. století (Oakeshott 1964, 102-103). Metrická i formální podobnost velkých skupin těchto mečů by mohla svědčit o jejich masové až sériové výrobě. Tuto možnost naznačuje i násadní otvor hlavice studovaného meče, který je výrazně rozměrnější než vlastní řap zbraně, jak to odhalil radiografický průzkum (obr. 5). Upevnění dané hlavice na řap bylo totiž možné jen díky zmenšení obou vstupních otvorů zpětným pěchováním zatepla, které bylo s velkou pravděpodobností až součástí adaptace již vyrobené hlavice na konkrétní čepel. Na tomto místě je třeba říci, že řemeslně dokonalejší, a pro pevnost usazení rukojeti výhodnější, by bylo naopak probití menších násadních otvorů v hlavici i záštitě, které by byly následně upraveny pilováním na konkrétní čepel. Tímto postupem by bylo možno trn i hlavici s čepelí velmi přesně spasovat, ovšem za cenu podstatného prodloužení doby výroby. To, že výrobce rukojeti postupoval opačně, tj. probil otvory polotovarů větší, než potřeboval, svědčí nepochybně o tom, že rychlost a snadnost operace měla přednost před pečlivostí a přesností.

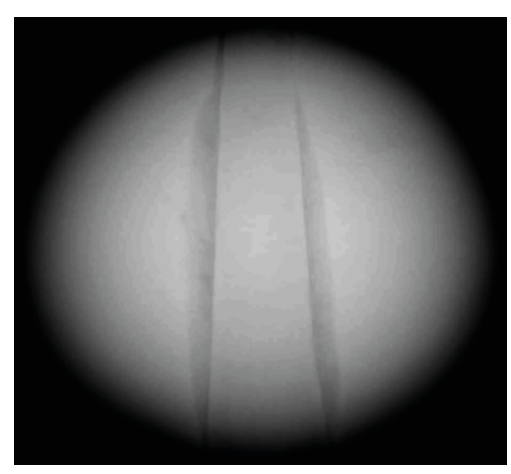

Obr. 5. Meč z Mouřínova rentgenový snímek hlavice meče s patrnou úpravou násadního otvoru. Foto J. Hošek.

Fig. 5. The Mouřínov sword - X-ray image of the pommel with a noticeable modification of the hole through which the tang runs. Photo by J. Hošek.
V drtivé většině jsou hlavice typu $H 1$ využity při konstrukci dlouhých mečů vybavených specifickým typem masivních čepelí hexagonálního průřezu typu XVII, ale často se objevují také právě na dlouhých mečích s čepelemi typu XVIa (např. Oakeshott 1964, 102-103; Aleksić 2007, 46-47; Žákovský 2009a, 516). Výjimku netvoří ani soubor materiálu, pocházející z území České republiky, odkud prozatím evidujeme, mimo studovanou zbraň, celkem 37 exemplářu těchto hlavic. Pomineme-li jejich solitérní nálezy (Hošek et al. 2019, kat. č. 45, 105, 110, 114 a 180), je 15 z těchto 37 zbraní vybaveno čepelemi typu XVII, přičemž je lze vesměs klasifikovat jako meče typu XVII, H1, 1 (Hošek et al. 2019, kat. č. 35, $149,178,269,279,293,295$ a 323), poprrípadě jako typ XVII, H1, 1 b (Hošek et al. 2019, kat. č. 36) či XVII, H1, 6a (Hošek et al. 2019, kat. č. 200 a 329). U řady těchto zbraní se však nedochovala záštita, takže je lze rámcově klasifikovat pouze jako meče typu XVII, H1, - (Hošek et al. 2019, kat. č. 206, 337, 338 a 384).

Dalších 12 mečů je vybaveno čepelemi typu XVIa, u nichž je ale celková variabilita o něco větší než u předešlých zbraní. Necháme-li stranou torza zbraní bez dochovaných záštit (Hošek et al. 2019, kat. č. 147), můžeme konstatovat, že se při jejich konstrukci uplatnily záštity typu 1 (Hošek et al. 2019, kat. č. 405), $1 b$ (Hošek et al. 2019, kat. č. 401), 2 (Hošek et al. 2019, kat. č. 48, 389, 390, 391), 5 (Hošek et al. 2019, kat. č. 412), 6 (Hošek et al. 2019, kat. č. 276, 291) a $6 a$ (Hošek et al. 2019, kat. č. 99, 182, 387). V menší míře pak byly hlavice typu $H 1$ aplikovány i na meče s čepelemi typu XIIa (Hošek et al. 2019, kat. č. 141, 322) a XIIIa (Hošek et al. 2019, kat. č. 99, 190).

Datování hlavic typu $H 1$ do průběhu 2. poloviny 14. století až 1. poloviny 15. století lze dokladovat i na našem materiálu. Do daného časového intervalu lze datovat solitérní nález hlavice z Litovle, která byla vyzvednuta z objektu datovaného obecně do průběhu 15. století (Hošek et al. 2019, kat. č. 110). Do počátku 15. století lze datovat i meč, který se dostal do země při likvidaci hradu v Lelekovicích v rámci markraběcích válek (např. Ptáčková, Unger 1994; 1999, 117-18; Hošek et al. 2019, kat. č. 99). S dobýváním hradu Lichnice husitským vojskem v roce 1428 nejspíše souvisí i náhodný nález torza řapu s hlavicí studovaného typu v blízkosti hradu (Hošek et al. 2019, kat. č. 105). Podobně jsme na tom při interpretaci nálezových okolností torza řapu s hlavicí typu $H 1$ z hradu Lopata na Plzeňsku, který byl v letech 1432-1433 dobýván husitským vojskem (Novobilský 2008, 89, obr. 97: 3; Hošek et al. 2019, kat. č. 114). Poněkud zvláštní místo mezi studovaným typem hlavic zaujímá hlavice $\mathrm{z}$ meče nalezeného při archeologickém výzkumu zaniklé vsi Mstěnice, která byla zničena za česko-uherských válek v roce 1468 (např. Krajíc et al. 1997; Hošek et al. 2019, kat č. 146). Drobná oválná hlavice bez zkosených hran by však mohla být klasifikována rovněž jako varianta hlavic typu $G$ a nelze ji proto jednoznačně použít jako doklad pro využívání hlavic typu $H 1$ ještě v průběhu 2. poloviny 15 . století.

Pro datování hlavic daného typu do přelomu 14. a 15. století svědčí i řada ikonografických pramenů. Dvě hlavice typu Hl nalezneme realisticky vyobrazeny např. na výjevu Ukřižování z dílny Mistra Paramentu z Narbonne, který vznikl v Paříži kolem roku 1375 (např. Fajt et al. 2006, 132-133, kat. č. 36.1). Masivní oválnou hlavicí zdobenou centrálně umístěným křrižem je vyzbrojena i postava sv. Palmácia z deskového obrazu Tommasa da Modena z kaple sv. Kř́íže na hradě Karlštejn, jenž je datován do 50. let 14. století (obr. 6; Fajt et al. 1997, 379).

\section{Záštita}

Meč z Mouř́nova je dále vybaven záštitou specifického tvaru, kterou lze klasifikovat typem $1 b$, jímž M. Głosek doplnil Oakeshottův typologický systém (Głosek 1984, 39-40, obr. 4). Pro tyto záštity jsou charakteristická mírně k čepeli prohnutá 


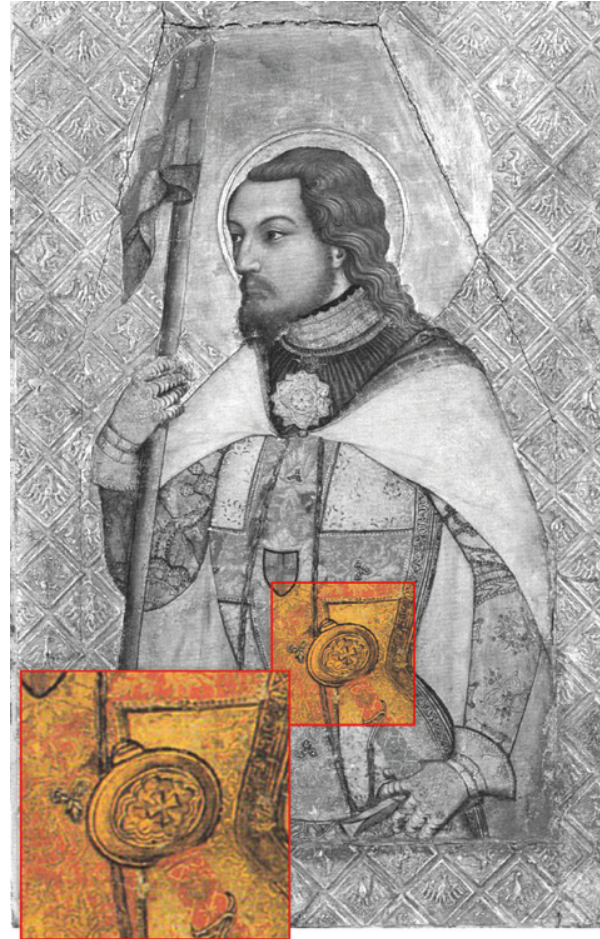

Obr. 6. Meč s oválnou hlavicí typu $H 1$ na deskovém obraze s postavou Sv. Palmácia z dílny Tommasa da Modena z kaple svatého Kř́íže na Karlštejně, mezi 1355-1359. Podle Fajt et al. 1997, 379

Fig. 6. Sword with an oval Type H1 pommel on a desk painting depicting St Palmatius by the workshop of Tommaso da Modena, featured in the Chapel of the Holy Cross at Karlštejn, 1355-1359. After Fajt et al. 1997, 379.

ramena kvadratického či obdélného průřezu, jejichž konce jsou bud'to svinuty do volut, nebo jsou jen zahnuty vzhůru směrem k rukojeti. Některými autory byly považovány za výrobky dílen působících na území dnešního Polska, a to v důsledku většího počtu registrovaných nálezů na polském území (např. Głosek, Nadolski 1970, 23-24; Głosek 1973b, 82; Glosek 1984, 39-40). Z území České republiky máme prozatím, pomineme-li meč $\mathrm{z}$ Mouřínova, $\mathrm{k}$ dispozici dalších 8 exemplářù těchto záštit (Hošek et al. 2019, kat. č. 2, 36, 96, 275, 278, 306, 330 a 395). Ojedinělí představitelé pak byly registrovány i v oblasti západní a jižní Evropy (např. Laking 1920a, 135; Hoffmeyer 1954, 33, 37, 40, tab. XXXII: a, XXXVII: a; Ward-Perkins 1967, tab. V; Oakeshott 1964, 138, obr. 125; Alexander 1985, 87, obr. 33). Z oblasti jihovýchodní Evropy však prozatím jejich zástupce neregistrujeme (srov. Aleksić 2007). Toto doposud evidované územní rozšíření záštit typu $1 b$ by mohlo tedy skutečně ukazovat na jejich původ v užší oblasti střední Evropy.

Obecně platí, že záštity typu $1 b$ se objevují takřka výhradně na dlouhých mečích s čepelemi typu XIIIa a XVIa a oktogonálními hlavicemi typu II (např. Głosek 1973b, 144-145, tab. XVI: 1, XXVI: 1, XXVIII: 2; Glosek 1984, 158, kat. č. 264, 272, 398; Małowiecki 1989; Liwoch 2010; Hošek et al. 2020). Tomu částečně odpovídá i materiál z území České republiky. Také zde se vážou záštity typu $1 b$ především na dlouhé meče vybavené masivními oktogonálními hlavicemi typu II (Hošek et al. 2019, kat. č. 2, 275, 278 a 306). V ojedinělých př́ípadech byly použity u mečů s hlavicemi typů G3, T2 a H1 (Hošek et al. 2019, kat. č. 395, 330 a 36). Oproti polskému materiálu však záštity typu $1 b$ z území České republiky nacházíme zejména na dlouhých mečích s čepelemi hexagonálního průřezu typu XVII (Hošek et al. 2019, kat. č. 2, 36,330 a 395) a v jednotlivých př́padech i s čepelemi typů XIIa, XVIa a XX (Hošek et al. 2019, kat. č. 306, 278 a 275).
Jak v českém, tak polském materiálu se projevuje vazba záštit typu $1 b$ na meče s hlavicemi typu $I 1$, což by zdánlivě mohlo naznačovat jejich společný původ. Proti této teorii však hovoří využití vcelku rozdílných typů čepelív obou oblastech. Zajímavé je i to, že jen na nepatrné části z těchto zbraní se setkáváme se signaturami, které lze hypoteticky spojit s výrobním centrem v Pasově. Z polského území je tzv. pasovským vlkem značena čepel nelokalizovaného dlouhého meče ze sbírek Muzeum Wojska Polskiego ve Varšavě (Głosek 1984, 169, kat. č. 398) a čepel jednoho meče, nalezeného u hradu Ciechanów (Małowiecki 1989). Z našeho území je pak značen biskupskou berlou pouze nelokalizovaný meč ze sbírek Muzea města Brna (Hošek et al. 2019, kat. č. 278). To by mohlo naznačovat, že zbraně tohoto typu byly vesměs produktem dílen mimo bavorský výrobní okruh, respektive nebyly zřejmě využívány importované čepele z této výrobní oblasti, a mohly být tedy produkovány někde v širší středoevropské oblasti, jak bylo naznačeno výše.

Obecně pak lze říci, že záštity typu $1 b$ se objevují především na zbraních, které lze datovat do 2 . poloviny 14. až 1 . poloviny 15. století. S tím zcela korespondují i ikonografické prameny, kde se tyto záštity v omezené míře vyskytují. Za všechny stačí uvést alespoň vyobrazení meče, kterým je vyzbrojen jeden ze zbrojnošů na desce Ukřižování z oltáře z Hronského Beňadiku, který byl vytvořen patrně v roce 1427 Tomášem z Kološváru (obr. 7; např. Bartlová 2001, 152-153, obr. 34; Fajt et al. 2006, 583-585, kat. č. 215; Poszler 2006, 580-586, kat. č. 7.19). Záštitou typu $1 b$ je vybaven rovněž meč, jejž třímá v ruce sv. Kateřina $z$ obrazu Tři světice z dílny tzv. Mistra Třeboňského oltáře, který byl zhotoven někdy mezi lety 1380-1385 (např. Matějček 1950, 90-91, obr. 93).

V př́ípadě meče z Mouřínova je na jeho záštitě pozorovatelných několik konstrukčních zajímavostí. Otvor pro navlečení na řap byl do záštity probit mnohem rozměrnější, než by bylo pro osazení na řap třeba. Přesto bylo nutné ji na čepel usadit, aby se záštita přizpůsobila konkrétnímu přechodu mezi řapem a čepelí. Je to obvyklá výrobní operace, která je nutná zvláště v př́ípadě,

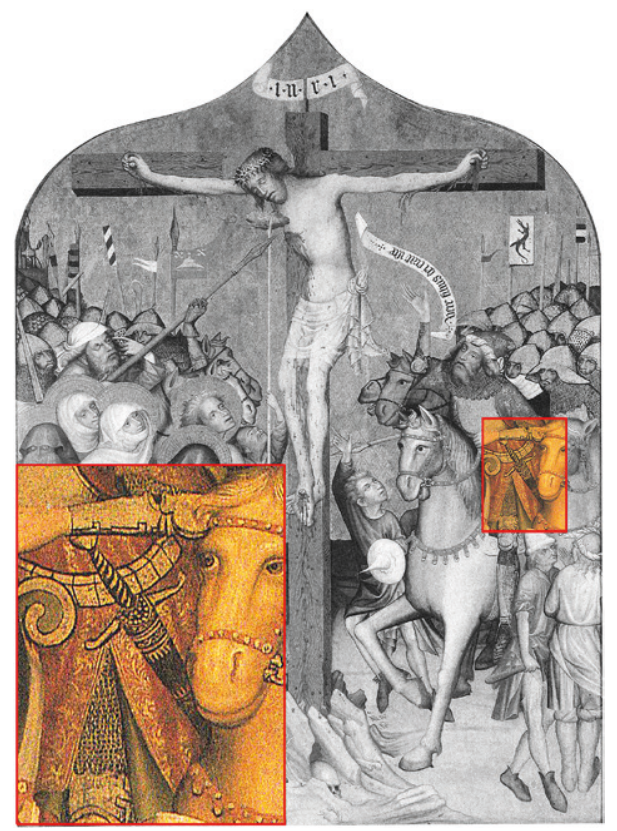

Obr. 7. Meč se záštitou typu $1 \mathrm{~b}$ na deskovém obraze Ukřižování z oltáře z Hronského Beňadiku z dílny Tomáše z Kološváru, kolem 1427. Podle Poszler 2006, kat. č. 7.19. Fig. 7. Sword with a Type $1 \mathrm{~b}$ crossguard on the Calvary altarpiece by Thomas de Coloswar from Hronský Beňadik, around 1427. After Poszler 2006, cat. no. 7.19. 
kdy přechod čepele do řapu je asymetrický, jako je to právě zde u námi studovaného kusu, kde jedna strana přechodu svírá úhel $90^{\circ}$, zatímco druhá pouze cca $45^{\circ}$ (obr. 8). To při vlastním usazování způsobilo, že na místě s menším úhlem došlo k prohnutí jednoho ramene záštity směrem k čepeli, nebot se zde záštita nemohla opř́t o ostrý přechod řapu v čepel, jako tomu bylo na druhé straně (obr. 9). Je zjevné, že bylo třeba velké síly $k$ dosažení tvaru ohybu, a je proto velmi pravděpodobné, že k usazení záštity na čepel došlo naražením kladivem zatepla. $Z$ výše uvedeného vyplývá, že prohnutí záštity nelze nejspíš považovat za cílenou změnu tvaru, ale spíše druhotný důsledek kompletace rukojeti meče spolu s existencí nesymetrického přechodu mezi jeho řapem a čepelí.

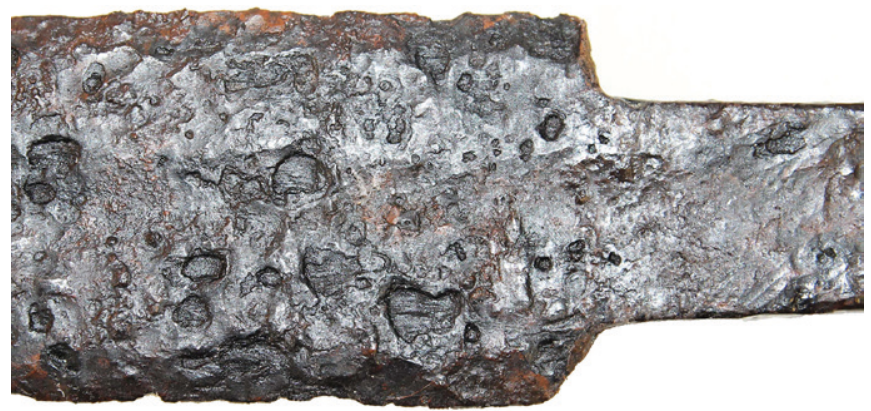

Obr. 8. Meč z Mouřínova - detail asymetrického odsazení řapu od čepele. Foto P. Zákovský.

Fig. 8. The Mouřinov sword - detail of the asymmetrical blade shouldering. Photo by P. Žákovský.

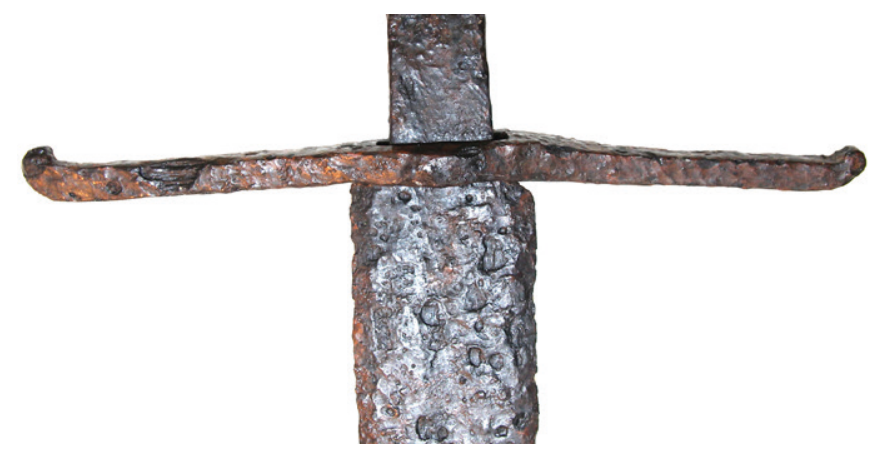

Obr. 9. Meč z Mouř́nova - detail záštity s patrným přizpůsobením jednoho ramene asymetrickému odsazení řapu. Foto P. Žákovský.

Fig. 9. The Mourínov sword - detail of the crossguard with a noticeable adaptation of one of the quillons to the asymmetrically shouldered blade. Photo by P. Zákovský.

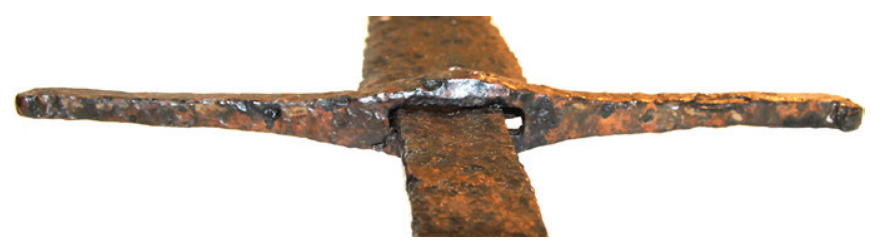

Obr. 10. Meč z Mouř́nova - detail záštity z nadhledu s patrným násadním otvorem, nekorespondujícím s rozměry řapu. Foto P. Žákovský.

Fig. 10. The Mourínov sword - top view of the crossguard with a visible opening, which does not correspond to the dimensions of the tang. Photo by P. Žákovský.
Jak bylo již zmíněno výše, je násadní otvor záštity mouřrinovského meče výrazně rozměrnější než samotný kořen řapu (obr. 10). Společně se zjištěnými konstrukčními detaily hlavice by tento fakt mohl svědčit pro využití předpřipraveného univerzálního polotovaru záštity v rámci kompletace zbraně. Podobný konstrukční detail nalezneme mimochodem na celé řadě vrcholně a pozdně středověkých mečů. Za všechny lze uvést analogickou záštitu typu $1 b$ dlouhého meče, který byl nalezen v roce 1928 společně s kosterními pozůstatky jezdce i koně v někdejší osadě Rakowice, která je dnes součástí Krakowa (např. Bocheński 1937, 54-55, obr. 3; Głosek, Nadolski 1970, 15, 40, kat. č. 27, tab. IX; Glosek et al. 1978, 36, kat. č. 82, tab. 20; Cabalska, Mazur 1982, 9, 13; Glosek 1984, 158, kat. č. 264, tab. XXXI: 3; Glinianowicz 2005, 153-154, tab. VIII: 2; Liwoch 2010, 107-109, obr. 1-3). I záštita tohoto meče má výrazně předimenzovaný násadní otvor, jak je dobře patrné zejména z nadhledu (Liwoch 2010, obr. 3).

\section{Značky}

Oproti celkem jednoznačnému datování mouřínovského meče do přelomu 14. a 15. století je otázka jeho provenience problematičtější. Jak bylo naznačeno výše, některé markanty na studované zbrani ukazují, že by se nutně nemuselo jednat o komplexní výrobek jedné mečířské dílny. S ohledem na dosud evidovaný nálezový korpus záštit typu $1 b$, respektive jejich územní rozšíření, lze hledat výrobu garnitury rukojeti pouze obecně v širší oblasti střední Evropy. Pro určení pravděpodobné provenience čepele pak lze do jisté míry využít značky, které jsou přítomny po obou jejích plochách.

Nejblíže k jílci, takřka u samotného kořene čepele, se na řadě mečů objevují značky, které jsou oproti značkám situovaným dále od záštity většinou rozměrově výrazně menší. Takovéto signatury jsou v literatuře, byt’ s určitými výhradami, interpretovány jako individuální znaky mečířských mistrů (např. Głosek 1973b, 118124; Głosek 1973a, 326-327, obr. 1; Głosek 1984, 52, 62-63). Z území České republiky byly takové značky prozatím zjištěny pouze na 18 mečích (Hošek et al. 2020).

Po obou plochách čepele meče z Mouřínova se těsně pod záštitou vyskytuje značka, jejíž podobu lze interpretovat jako tzv. vidlicový či lotrovský kř́žz (obr. 11: a-b). Tato signatura se jeví jako prozatím velmi ojedinělá. Musíme mít však na paměti, že právě značky umístěné na čepeli těsně či v menší vzdálenosti pod spodní hranou záštity se vyznačují mnohdy nepatrnými rozměry. Z tohoto důvodu nemusejí být vždy evidovány či správně interpretovány. Analogickou značkou je opatřena např. čepel blíže nelokalizovaného nálezu dlouhého meče typu XVII, I, I z přelomu 14. a 15. století ze sbírek Muzea Narodowe ve Wrocławiu. Zde jsou tyto značky doprovázeny dalšími merkami v podobě maltézského kříže v kruhu a golgotského kř́iže či stylizovaného ř́ı̌ského jablka (Głosek 1973b, kat. č. 77, tab. XLIV: 1; Głosek 1984, kat. č. 416). Maltézským kř́ížem v kruhu je doprovázena značka ve tvaru vidlicového kř́íže také na dlouhém meči typu XXI, Z, 12 z průběhu 15. století ze sbírek Magyar Nemzeti Múzeum v Budapešti (Głosek 1984, kat. č. 484) či na dlouhém meči z průběhu 15. století z bývalé sbírky Karla Gimbela ( $\mathrm{Ru}-$ dolph Lepke's 1904, 20, kat. č. 348). Stejnou kombinaci signatur nalezneme rovněž na dlouhém meči z průběhu 14. století z bývalé sbírky Maxe Kuppelmayra (Kuppelmayr 1895, 18, kat. č. 194).

Ani podoba další značky z mouřínovského meče nepatří zrovna k běžným. Představuje diagonálu tvořenou trojicí drobných rovnoramenných kř́ížo̊ (obr. 11: c-d). Jednotlivé křížky byly původně tauzovány či za tepla inkrustovány neželezným kovem, který byl na základě rentgen-fluorescenční analýzy identifikován jako mosaz (tab. 1); tato výplň se dodnes dochovala pouze v jediném kř́ǐzu (obr. 12). 

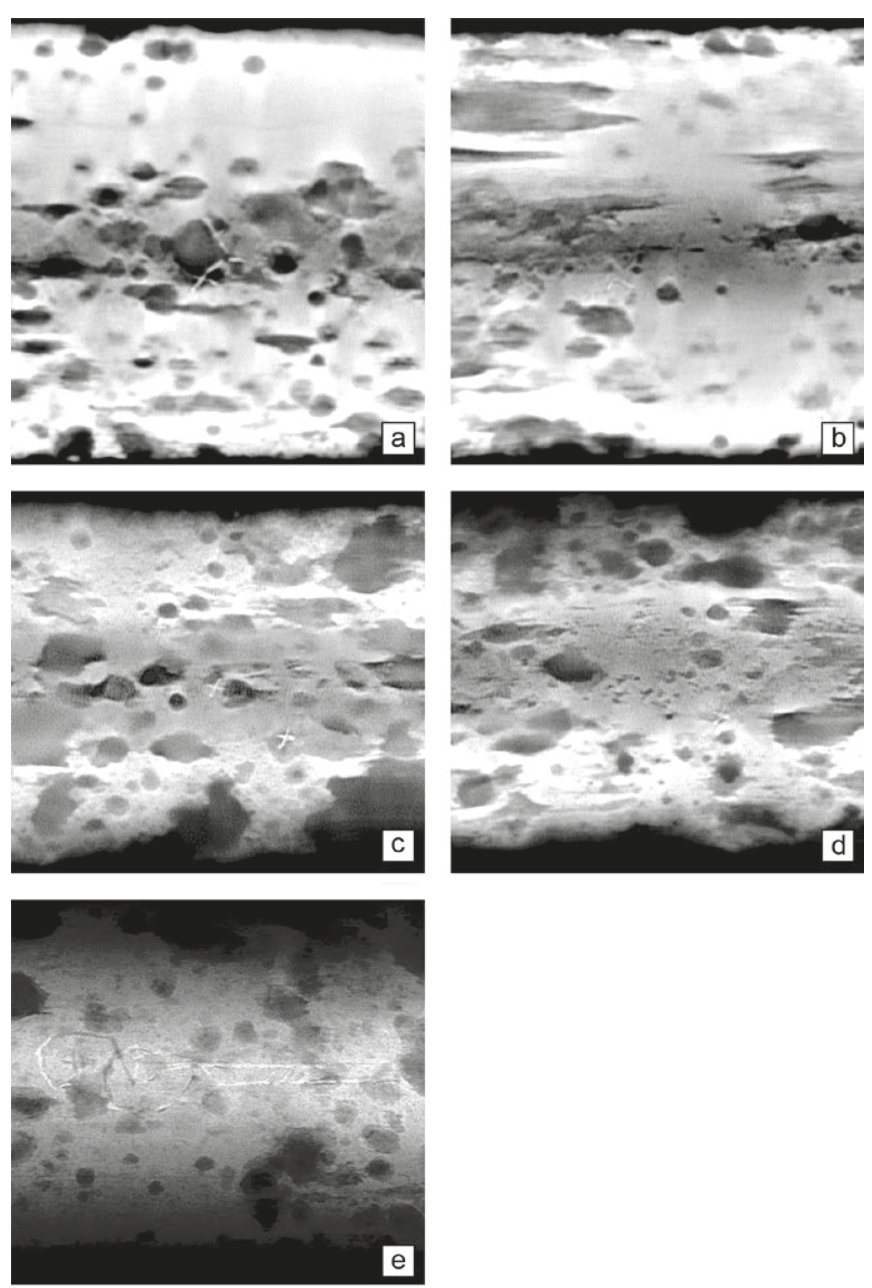

Obr. 11. Meč z Mouřínova - značky zachycené na čepeli jednak pomocí rtg. výpočetní tomografie (a, c - jedna strana čepele, b, d - druhá strana), jednak běžným rtg. snímkováním ( $\mathrm{d}$ - překryté znaky z obou stran); a, b - vidlicový kř́ǐz; c, d - diagonála ze tří drobných křížků; e - biskupská berla. Foto J. Hošek.

Fig. 11. The Mouřinov sword - marks on the blade revealed by both the X-ray computed tomography (a, c - one side of the blade, $b, d$ - the other side of the blade) and common $X$-ray imaging ( $d$ - overlapping characters on both sides); $a, b$-forked cross; c, $d$-a diagonal consisting of three small crosses; e - bishop's crosier. Photo by J. Hošek.

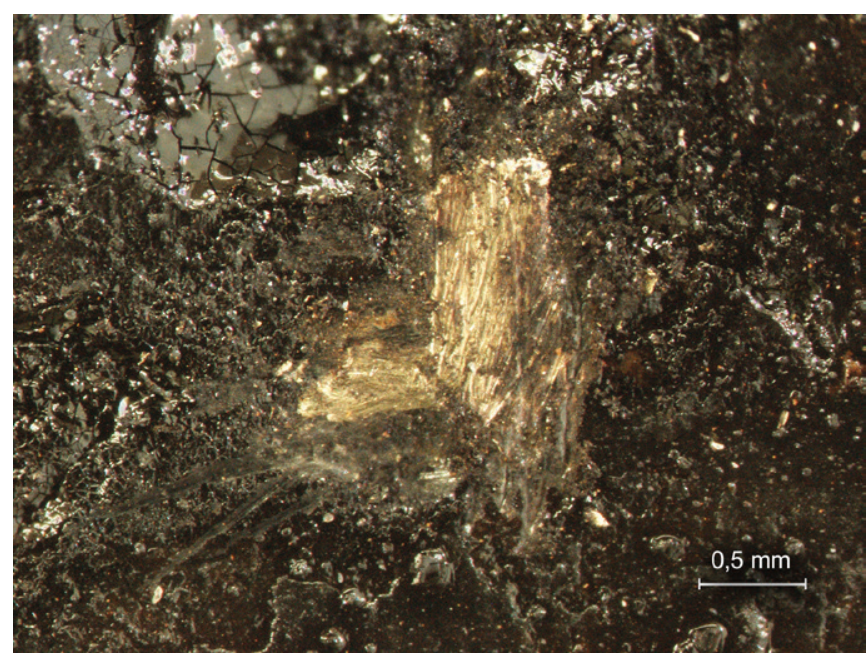

Obr. 12. Meč z Mouřínova - detail dochované inkrustační výplně z jedné ze signatur. Foto M. Kmošek.

Fig. 12. The Mourínov sword - detail of inlaying metal preserved in one of the signatures. Photo by M. Kmošek.

\begin{tabular}{lllllllll}
\hline Prvek & $\mathrm{Cu}$ & $\mathrm{Fe}$ & $\mathrm{Zn}$ & $\mathrm{Pb}$ & $\mathrm{Ni}$ & $\mathrm{Sn}$ & $\mathrm{Co}$ & $\mathrm{Mn}$ \\
\hline Hm. \% & 53,29 & 29,13 & 16,62 & 0,49 & 0,3 & 0,08 & 0,08 & 0,03 \\
\hline
\end{tabular}

Tab. 1: Prvkové složení výplně značky čepele a okolní matrice stanovené XRF analýzou.

Tab. 1: Elemental composition of the blade mark's filling and the surrounding matrix determined by XRF analysis.

Takovéto signatury patřri i v evropském měřítku ke zcela ojedinělým jevům a většinou je nacházíme v kombinaci se značkami dalších forem. Doposud, mimo studovaný meč, máme informace pouze o třech exemplářích dlouhých mečů, které jsou trojicemi diagonálně umístěných křížků opatřeny. Tato situace však může být opět způsobena poměrně malými rozměry těchto značek, které při pouhém makroskopickém průzkumu zbraně nemusí být vždy patrné, a rozpoznány bývají až při rtg. průzkumu. Ostatně tak tomu bylo i v našem případě. Na dlouhém meči ze sbírek Landesmuseum Grimma jsou diagonály sestavené z trojice rovnoramenných kř́ižků kombinovány se signaturami v podobě stylizovaného ř́šssého jablka a pastorálu (Gurlitt 1897, 118, obr. 158; Głosek 1984, 153, kat. č. 207, tab. XII). V poněkud modifikované formě je trojice značek př́tomna také na dlouhém meči typu XVIa , T1, 1 pocházejícím z hradu Lanzkron v Pomořansku. Na této zbrani se objevují značky v podobě kř́iže vyrůstajícího ze srdce, diagonály sestávající z trojice drobných rovnoramenných kř́žž ů a biskupské berly (Głosek 1984, 148, kat. č. 140, tab. VIII). Obdobnou kompozici nalezneme rovněž na dlouhém meči typu XVIa, H1, 2 ze sbírek Vojenského historického ústavu v Praze (obr. 13). Oproti meči z Lanzkron se na jeho čepeli objevují dvě souběžné diagonály tvořené šesticí rovnoramenných kř́žků (např. Głosek 1984, 144, kat. č. 93; Žákovský et al. 2017, 167, obr. 19: b; Hošek et al. 2019, kat. č. 389). Poněkud modifikovanou sestavu těchto signatur nalezneme rovněž na solitérní čepeli typu XVIa ze sbírek Muzeum Narodowe ve Wrocławiu. Na této čepeli se totiž setkáváme $\mathrm{s}$ kombinací kříže vyrůstajícího ze srdce a pastorálu, kterou doplňuje rozměrný křížkový kř́iž, který v daném př́ípadě nahrazuje diagonály sestavené z drobných kř́ížku známé z ostatních výše uvedených zbraní (Głosek 1973b, 158, kat. č. 75, tab. XXXVI: 1; Głosek 1984, 171, kat. č. 413, tab. XVI). Pootočení i typ tohoto kř́iže však naznačuje, že je to opravdu jen variace na téma studovaných diagonál.

Již na první pohled zaujme, že všechny výše zmíněné zbraně nesou na svých čepelích i signatury v podobě pastorálu, což by mohlo svědčit o společném původu těchto čepelí v pasovských dílnách. S výraznými značkami v podobě biskupské berly se ostatně shledáváme i na meči z Mouřínova, kde ve shodě s výše jmenovanými zbraněmi opticky ukončují žlábky čepele (obr. 11: e). Oproti výše popsaným typům značek patří signatury v podobě pastorálu $\mathrm{k}$ jedněm $\mathrm{z}$ nejrozšířenějších vůbec. Většinou se na zbraních objevují v kombinaci s dalšími merkami, především různými tvary kř́ižů, říšského jablka či kříže vyrůstajícího ze srdce apod. (srov. Głosek 1984, 61-62; Žákovský 2012, 634-635). Tomu odpovídá i prozatím evidovaný materiál z území České republiky, odkud máme dosud $\mathrm{k}$ dispozici, pokud nepočítáme meč z Mouřínova, 16 dalších exemplářu takto značených dlouhých mečů. Na dlouhém meči z přelomu 14. a 15. století typu XIIIa, I1, 7, který byl nalezen při archeologickém výzkumu v centru Staré Boleslavi, byla značka v podobě pastorálu doprovázena řadou dalších, dnes bez podrobnějšího průzkumu blíže neinterpretovatelných značek (Hošek et al. 2019, kat. č. 11). Ze stejného období pochází rovněž torzo dlouhého meče typu XVIa, H1, - , značeného biskupskou berlou a maltézským křížem v kruhu (Hošek et al. 2019, kat. č. 147), které bylo nalezeno v areálu hradu Mydlovar. Ze sbírek Muzea města Brna pochází 


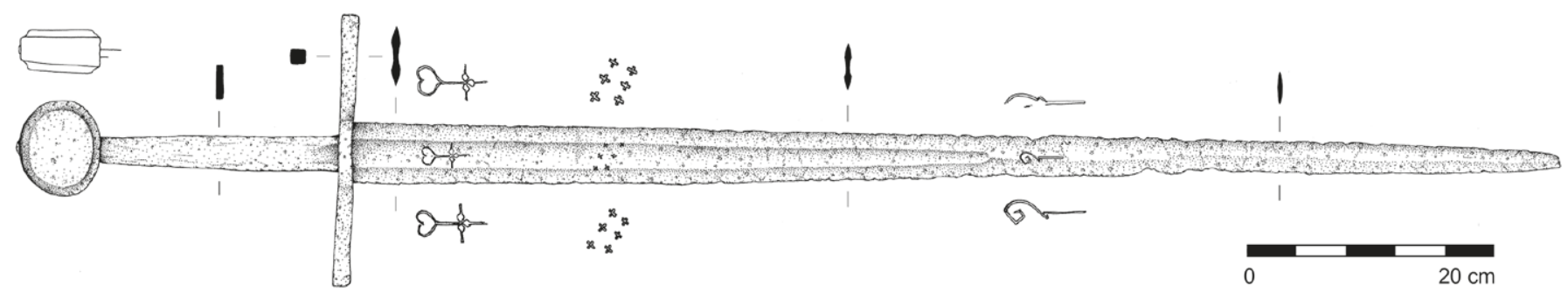

Obr. 13. Blíže nelokalizovaný dlouhý meč z přelomu 14. a 15. století ze sbírek Vojenského historického ústavu v Praze s podobnou skladbou signatur. Podle Hošek et al. 2019, cat. ID No 389.

Fig. 13. A non-localised sword from the turn of the $15^{\text {th }}$ century from the collections of the Military History Institute in Prague with a similar set of signatures. After Hošek et al. 2019, cat. ID No 389.

blíže nelokalizovaný dlouhý meč z průběhu 14. století typu XVIa, Il, $1 b$, který je mimo značku v podobě biskupské berly značen i signaturou v podobě říšského jablka či golgotského kř́íze (Hošek et al. 2019, kat. č. 278). Ani u dalších mečů, u nichž se signatury v podobě biskupské berly objevují zdánlivě samostatně, nelze bez podrobnějšího průzkumu vyloučit, že jsou ve skutečnosti rovněž kombinovány s dalšími značkami (Hošek et al. 2019, kat. č. 146, 183, 200, 271, 337 a 414).

Je příznačné, že biskupskou berlou je značena i řada tzv. rychtářských či soudních mečů (tzv. Gerichtsschwert) z českých a moravských sbírek, které pocházejí z přelomu 15. a 16. století (Žákovský 2012; Hošek et al. 2019, kat. č. 166, 288, 362, 426 a 427). Vesměs se jedná o náročně koncipované řemeslné výrobky s mnohdy velice složitou a originální konstrukcí rukojeti, které ve své době plnily funkci symbolu soudní pravomoci. Jelikož tyto meče plnily především reprezentativní funkci, byla výrobci věnována i velká pozornost jejich výzdobě. V této souvislosti neníbez zajímavosti, že se někdy zhotovení tzv. rychtářského či soudního meče uvádí i jako součást mistrovských zkoušek v rámci mečířského cechu, jak to máme doloženo např. cechovním řádem z roku 1497 z polské Poznaně (Maisel 1961, 280; Trzciński 2001, 65). Není proto překvapivé, že představení jednotlivých měst se snažili prezentovat svoji moc i tímto symbolem své vlády, svrchovanosti a soudní pravomoci, přičemž tyto zbraně objednávali velmi často v soudobých vyhlášených výrobních centrech. Tato skutečnost sama o sobě měla nepochybně zvýšit prestiž daných úřadů a zároveň vizualizovala i hospodářskou a kulturní úroveň daného města. O objednávce těchto zbraní v tehdejších významných výrobních střediscích svědčí především signatury, se kterými se na těchto specifických mečích setkáváme v hojnější míře. Jsou to především různé formy tzv. říšského jablka či golgotského kř́ǐ̌e, které však nelze jednoznačně spojit s žádným konkrétním výrobním stř̌ediskem. Jinak jsme na tom u mečů signovaných tzv. pasovským vlkem, které lze s největší pravděpodobností spojit $\mathrm{s}$ dílnami v bavorském Pasově a v menší míře s dílnami v Solingenu, přestože i u některých rychtářských mečů se poněkud paradoxně setkáváme s falšovanými značkami (např. Kühn 1970, 105; Trzciński 2001, 65-67). Právě rychtářské meče signované pasovským vlkem jsou často opatřeny i značkou v podobě biskupské berly, která nepochybně odkazuje na biskupský statut města. O původu těchto zbraní, respektive čepelí v tomto vyhlášeném bavorském výrobním středisku, jehož produkce na přelomu 15. a 16. století prožívala jeden ze svých kvalitativních i kvantitativních vrcholů, nelze pochybovat (např. Uhlemann 1982, 33).
Z českého prostředí jsou kombinací značek v podobě tzv. pasovského vlka, respektive jednorožce a pastorálu signovány dva přepychové rychtářské meče. Jedním z nich je přebohatě zdobená zbraň se složitou konstrukční variantou rukojeti ze sbírek Státního hradu Buchlov (Hošek et al. 2019, kat. č. 288). Lze ji zařadit do specifické skupiny rychtářských či soudních mečů zhotovených patrně jednou $\mathrm{z}$ pasovských dílen někdy na přelomu 15. a 16. století (např. Leitner 1866-1870, 2, taf. II: 3; Trzciński 2001, 48-49, 92-95, fig. 20). Druhý exemplář představuje poněkud naddimenzovaný meč z přelomu 15. a 16. století ze sbírek Muzea hlavního města Prahy, o jehož původní funkci výmluvně svědčí i iniciálová inskripce na čepeli, doprovázející signatury odkazující na její pasovský původ (Hošek et al. 2019, kat. č. 362, tab. XVI: b). Po obou plochách této čepele jsou mezi značku v podobě tzv. pasovského vlka a pastorálu totiž vepsány majuskulní litery „RBI“, respektive „RDI“, které bychom snad mohli interpretovat jako iniciálovou zkratku slovního spojení „Regni Bohemiae Iustitia“.

Právě kombinace značek v podobě biskupské berly a tzv. pasovského vlka, př́ípadně jednorožce, byt̉ se neobjevuje na doposud registrovaném materiálu př́lišš často, podle našeho názoru výrazně promlouvá do diskuse o původu takto značených mečů a přibližuje nás tak i k případnému určení provenience čepelí, signovaných pouze značkou v podobě biskupské berly. Většina autorů spojovala tradičně takto značené čepele s výrobním střediskem v bavorském Pasově (např. Ehrenthal 1897, 8; Schmid 1920, 336; Seitz 1965, 178, obr. 114; Nickel 1974, 290; Huther 2007, 45), s čímž lze, i přes výhrady M. Głoska (Głosek 1973b, 92-93), na základě dosud zjištěných dat spíše souhlasit (např. Žákovský 2012; Hošek et al. 2020).

Obecně lze říci, že se značky v podobě biskupské berly počaly na zbraních objevovat až v průběhu 2. poloviny 14. století, přičemž jsou charakteristické zejména pro dlouhé meče $\mathrm{z}$ přelomu 14. a 15. století. Druhý vrchol jejich výskytu pak lze spatřovat na přelomu 15. a 16. století, kdy je jimi signována celá řada především rychtářských či soudních mečů. Sporadicky se však s nimi setkáváme ještě kolem poloviny 16. století. Tak např. k roku 1545 je datován ceremoniální meč ze sbírek Hofjagd- und Rüstkammer ve Vídni (Leitner 1866-1870, 3, tab. III: 1; Gamber, Beaufort 1990, 65-66, A 215), či meč Karla von Steiermark, který byl vyroben někdy kolem roku 1560 (např. Gamber, Beaufort 1990, 117-118, A 1135). U těchto zbraní však nelze zcela vyloučit možnost, že při jejich konstrukci byly využity starší čepele např. z komemorativních důvodů apod. Jisté však je, že studované značky nalezneme $\mathrm{v}$ ojedinělých př́ípadech ještě na kordových čepelích z přelomu 


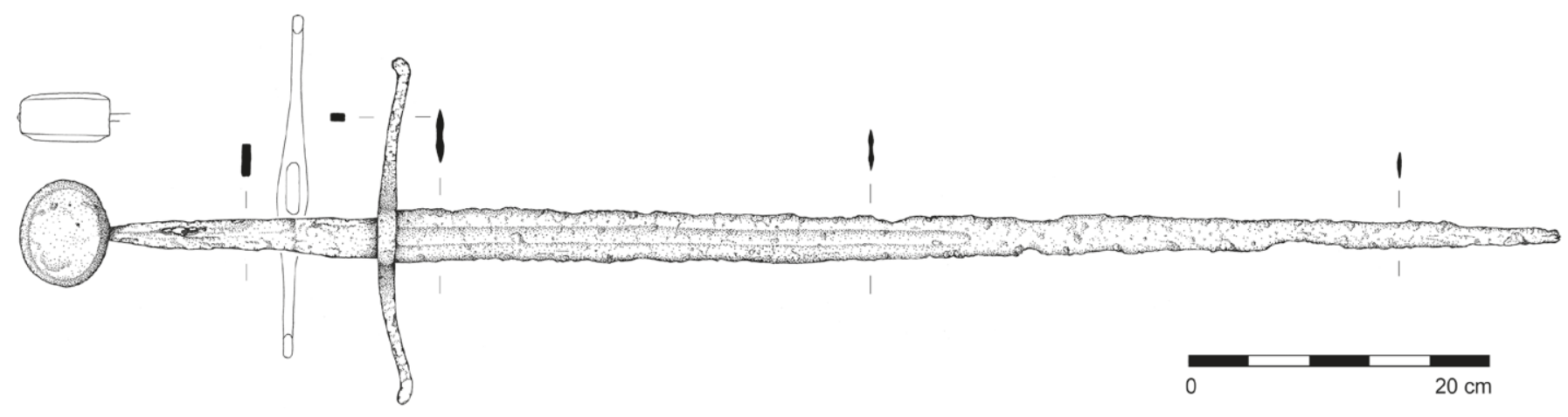

Obr. 14. Blíže nelokalizovaný meč z přelomu 14. a 15. století z expozice Informačního centra a Městského muzea v Přibyslavi. Podle Hošek et al. 2019, kat. č. 401.

Fig. 14. A non-localised sword from the turn of the $15^{\text {th }}$ century from the exposition of the Information Centre and Municipal Museum in Přibyslav. After Hošek et al. 2019, cat. no. 401.

16. a 17. století. Stačí zde uvést čepel kordu ze sbírek Museum für Deutsche Geschichte v Berlíně, jehož garnitura rukojeti byla zhotovena v Drážd’anech kolem roku 1600, čepel však v Pasově (Hiltl 1876, 69, kat. č. 404; Müller, Kölling 1986, 380, obr. 155).

Lze tedy konstatovat, že čepel meče z Mouřínova byla nejspíše vyrobena někdy na přelomu 14. a 15. století v bavorském Pasově, což s ohledem na obecné masové rozšíření produktů mečířského řemesla předpokládaného pasovského původu na našem území není nijak překvapující (srov. Hošek et al. 2020).

\section{Závěr}

Zbraň nalezenou v lesním komplexu Ždánického lesa je možné klasifikovat jako dlouhý meč typu XVIa, H1, Ib (podle E. Oakeshotta), který lze celkem spolehlivě datovat do přelomu 14. a 15. století. Přestože je zbraň složena z jednotlivých komponent, které se $\mathrm{v}$ evropském měřítku objevují samostatně poměrně hojně, přesných analogií ke studovanému meči nenalezneme mnoho. V korpusu mečů z území České republiky je např. zastoupen pouze jediný exemplář shodně typologicky klasifikovatelného meče, který je dnes součástí výstavní expozice v Přibyslavi (obr. 14; Hošek et al. 2019, kat. č. 401). V daném př́ípadě by se tak mohlo jednat o doklad předpokládaného obecného systému masové výroby vrcholně a pozdně stř̌edověkých mečů. Hypoteticky lze totiž předpokládat, že čepele byly masově až sériově vyráběny již za pomoci mechanizace (vodního hamru) především ve specializovaných střediscích, jako byly např. Pasov, Solingen či Kolín nad Rýnem, odkud byly distribuovány i do značně vzdálených oblastí (srov. Mäder 2013, 35-36). V místě určení pak mohli tamní mečíri importované čepele osadit lokálně preferovanými typy garnitur rukojetí. V našem případě by se jednalo o osazení čepele pasovské provenience garniturou jílce charakteristickou pro širší oblast stř̌ední Evropy. Dokládají to především signatury v podobě biskupské berly na čepeli a specificky tvarovaná záštita.

Jisté konstrukční detaily totiž naznačují, že by studovaná zbraň mohla být výsledkem výroby několika specializovaných řemeslníků, kteři mohli být na sobě zcela nezávislí. Záštita i hlavice meče mají totiž otvory pro provlečení trnu čepele probité zatepla, přičemž rozměry těchto otvorů nekorespondují, především ve své šírce, se skutečnými rozměry řapu meče. To by mohlo nasvědčovat, že při konstrukci zbraně byly použity předpřipravené polotovary, které byly posléze přizpůsobeny konkrétní čepeli. V př́padě našeho meče byla záštita, nejspíše zatepla, naražena na řap čepele, čímž došlo $\mathrm{k}$ jejímu usazení. Hlavice $\mathrm{s}$ probitým větším otvorem byla nejprve zatepla adaptována zakováním vstupních otvorů pěchováním, a potom byla, nejspíše zastudena, naražena na řap a zanýtována. Čepel sama má asymetricky odsazený řap, z jedné strany pod úhlem 90 a z druhé pod úhlem cca 45 . Je otázka, ukazuje-li tato skutečnost na nějaký funkční záměr výrobce, nebo jde o víceméně náhodnou nedokonalost výrobku. Protože si lze obtížně představit důvod takové asymetrie, je druhá možnost pravděpodobnější. V každém př́padě byla záštita při narážení zdeformována $\mathrm{v}$ místě, kde má odsazení čepele úhel 45, vlivem čehož došlo k jejímu prohnutí směrem $\mathrm{k}$ hrotu, nebot zde se tělo záštity neopíralo o čepel tak důkladně, jako na protější straně. Toto prohnutí je jednoznačně původu výrobního a nikoli důsledkem používání meče, či jeho archeologizace. Svědčí to o nepř́iliš vysoké pečlivosti věnované kompletaci zbraně, která je spíše průměrnou než špičkovou ukázkou tehdejšího řemesla. Dnešní estetické cítění, zejména pokud jde o vnímání symetrie, nemůžeme brát zcela $\mathrm{v}$ potaz, nebot by náš pohled byl zřejmě anachronický a do značné míry zkreslený. Středověký člověk symetrii a asymetrii vnímal totiž zřejmě poněkud jinak a tyto parametry pro něj nebyly př́liš podstatným hlediskem ve vnímání krásy či dokonalosti, pomineme-li ovšem díla tzv. vysokého umění, kde proporční estetika byla jedním ze základních uměleckých a estetických principů středověku, který do určité míry podmiňoval i samotný rozvoj př́ípadného ikonografického repertoáru (srov. Eco 1998, 61-62).

Meč z Mouřínova tak lze nejspíše přiřadit mezi čistě funkční a praktické zbraně. I takové meče však mohly ve své době plnit i jistou symbolickou roli, přestože na přelomu 14. a 15. století byla symbolická funkce mečů již částečně vyprázdněna, a to především v důsledku jejich snadné dostupnosti všem složkám tehdejší společnosti. Role meče jako statutárního symbolu rytířství či privilegovaného stavu svého nositele se patrně začala vytrácet rovněž ve spojitosti s postupným zánikem monopolu šlechty na vedení válek, což lze na základě řady dobových literárních zmínek v českém prostředí sledovat právě již v průběhu 14. století. Šlechta byla totiž v této době čím dál častěji nahrazována žoldnéřským vojskem či městskou hotovostí a postupně tak ztrácela svoji aureolu bojovníka a tím byla částečně otřesena i její pozice v rámci tripartitia jako bojovníků (bellatores) a ochránců ostatních dvou stavů. Tento fakt lze ostatně dát do souvislosti i s postupnou sémantickou proměnou samotného termínu „rytíru“, který od počátku 15. století označuje, kromě několika duchovních a encyklopedických textů, takřka výhradně př́íslušníka nižší šlechty, a ne bojovníka na koni, jak to bylo obvyklé v předcházejícím období (např. Macek 1997, 60; Iwańczak 2001, 108; Iwańczak 2011, 92). 
Symbolika meče se tak v této době spíše přesunula do právní roviny, kde meč plnil roli symbolu soudní pravomoci a výkonu veřejné moci obecně. Lze to demonstrovat např. na dlouhém meči typu XVIa, H1, 5 z přelomu 14. a 15. století, který byl v roce 1965 nalezen v hrobce biskupa Gerharda ze Schwarzburgu (1372-1400) ve würzburské katedrále a který zároveň představuje poměrně blízkou analogii $\mathrm{k}$ meči $\mathrm{z}$ Mouř́nova. Kompletně dochovaný meč v pochvě omotané opaskem doprovázel v hrobové výbavě typické biskupské insignie, jako byly pontifikální rukavice, patena s kalichem a krásně zdobený pastorál (obr. 15). Meč byl v tomto případě nepochybně biskupovi do hrobu přidán jako symbol jeho soudní pravomoci, což ostatně odkazuje na starší tradici.

Zda mohl meč z Mouř́nova plnit mimo svou praktickou funkci i nějakou funkci symbolickou, je však dnes nemožné rozhodnout. Zbraň totiž byla nalezena mimo sídelní oblast a místo její archeologické transformace nebylo situováno ani poblíž nějaké fungující či zaniklé komunikace. Pouze v hypotetické rovině by mohl mít meč jistou souvislost s nedalekým opevněným sídlem
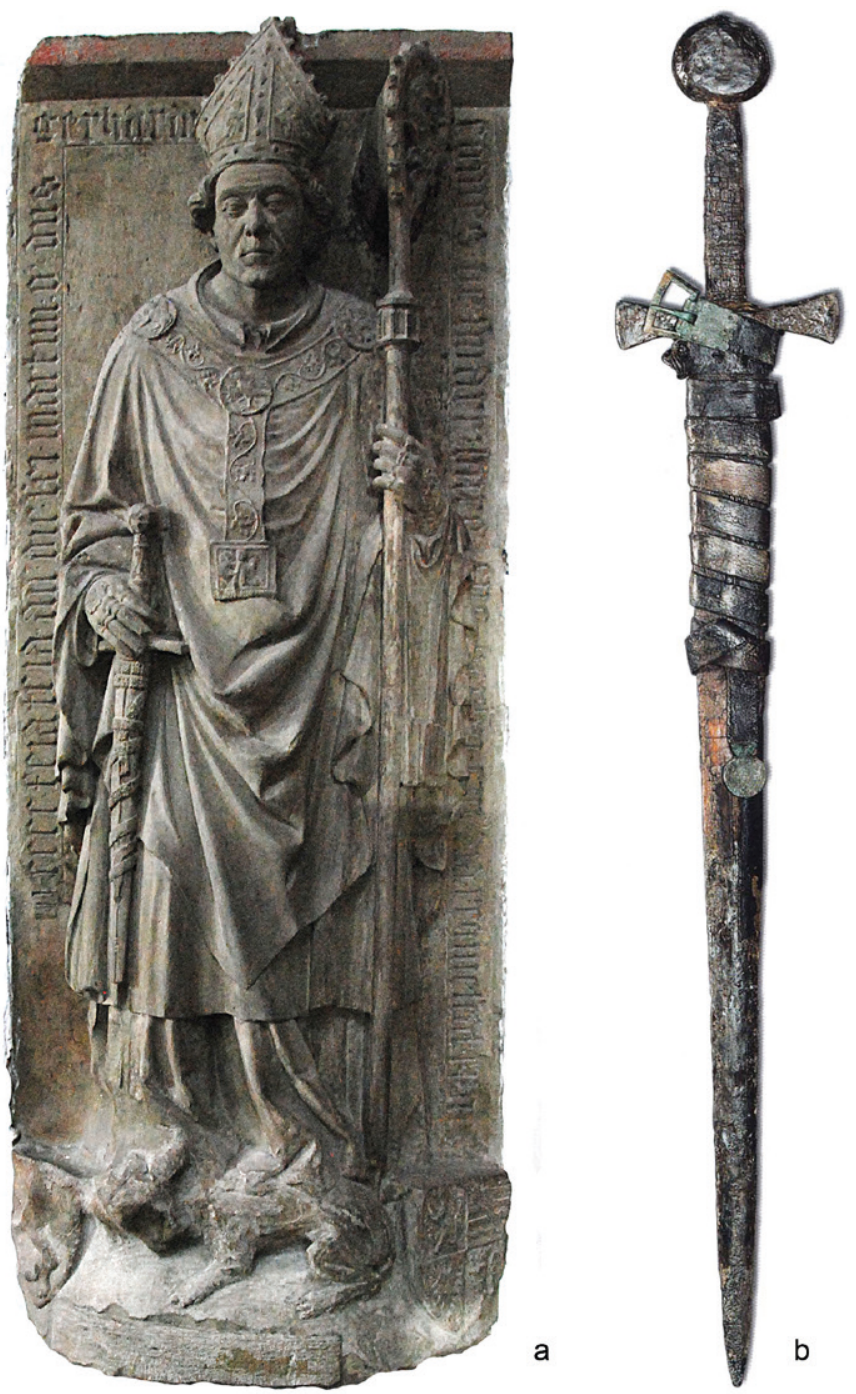

Obr. 15. a - figurální náhrobek biskupa Gerharda ze Schwarzburgu († 1400) ve würzburské katedrále; b - dlouhý meč v pochvě z hrobové výbavy biskupa Gerharda ze Schwarzburgu z katedrály ve Würzburgu. Podle Schneider 2004, kat. č. 53.

Fig. 15. a - the figural tombstone of Bishop Gerhard of Schwarzburg († 1400) in Würzburg Cathedral; $b$ - long-sword in a scabbard, part of the grave goods of Bishop Gerhard of Schwarzburg in Würzburg Cathedral. After Schneider 2004, cat. no. 53 . v poloze Hradisko, v literatuře známým i jako Újezd či Lhota u Ždánic, či se stejnojmennou zaniklou vsí, která s tímto opevněným sídlem měla zřejmě úzký vztah. Tato fortifikace je však dodnes blíže nedatována, a některými autory je dokonce považována za nedokončenou stavbu (např. Unger 1992, 248-249; Plaček 2001, 249-250). Od místa nálezu zbraně se oba tyto sídelní areály nacházejí zhruba necelý kilometr vzdušnou čarou přes nevýrazné údolí. S ohledem na předpokládaný vznik meče někdy na přelomu 14. a 15. století nelze ani vyloučit možnost, že zbraň mohla být ztracena v místech nálezu někdy v době feudálních rozbrojů a domácí války na přelomu těchto dvou století či v turbulentní době husitských válek, kdy v daném regionu zanikla i řada lidských sídel (srov. Chaloupka 1965, 66-69; Měchurová 1997, 12-15; Měřínský 1997, 68-88).

\section{Poděkování}

Studie vznikla s institucionální podporou na dlouhodobý koncepční rozvoj výzkumné organizace RVO: 68081758 - Archeologický ústav AV ČR, Brno, v. v. i.

\section{Poznámky}

1. M. Aleksić při srovnání těchto dvou základních typů čepelí vrcholně středověkých dlouhých mečů došel k závěru, že čepele typu XVIa byly oproti čepelím typu XIIIa progresivnější především v tom, že jejich těžiště bylo posunuto více směrem k rukojeti, čímž měla být zajištěna snazší manipulace se zbraní (Aleksić 2007, 89). Tento předpoklad se však na materiálu z území České republiky nepodařilo potvrdit, nebot zde se pohybuje vzdálenost těžiště od záštity na obou typech čepelí v takřka shodných dimenzích v poměrně širokém rozsahu 40-180 mm, přičemž většina těchto zbraní je opatřena těžištěm ve vzdálenosti zhruba $80-120 \mathrm{~mm}$ od záštity (Hošek et al. 2020).

2. Analýza prvkového složení byla provedena pomocí ručního spektrometru Niton XL3t 950 GOLDD (Rh rentgenka, mód General metals, doba měření 60 sekund, urychlovací napětí $50 \mathrm{kV}$, kolimátor 8 a $3 \mathrm{~mm}$ ) s integrovaným automatickým vyhodnocením spekter.

3. S diagonálou tvořenou drobnými rovnoramennými kř́ižky se zcela ojediněle můžeme setkat ještě na pozdějších zbraních, jak to dokládá např. čepel luxusního ceremoniálního meče, datovaného kolem poloviny 16. století ze sbírek Kunsthistorische Museum ve Vídni. Bez zajímavosti není, že i původ této zbraně či alespoň její čepele je shledáván v Pasově (např. Leitner 1866-1870, 3, tab. III: 1; Gamber, Beaufort 1990, 65-66).

4. V tomto ohledu nelze souhlasit s tvrzením polského badatele M. Trzcińského, který konstatoval, že soudní, neboli rychtářské meče, nebyly ve většině případů signovány, a proto uvažoval o jejich výrobě místními dílnami (Trzciński 2001, 71). Dosud evidovaný materiál z území České republiky však jednoznačně hovoří proti tomuto předpokladu.

5. Jisté paralely k této čepeli představují dva kompletně dochované meče ze sbírek Hofjagd- und Rüstkammer ve Vídni, které jsou však opatřeny iniciálovými inskripcemi christologického obsahu (Leitner 1866-1870, 2-3, tab. II: 5, 8; Gamber 1961, 26-27, obr. 18; Thomas, Gamber 1976, 76, A 89 W).

6. Touto kombinací značek jsou signovány např. čepele mečů ze sbírek Royal Armouries v Leedsu (např. Laking 1920b, 329, obr. 707; Seitz 1965, 164, obr. 102; Dufty 1974, 16, tab. 10: a; Norman, Wilson 1983, 45-46, kat. č. 15), Hofjagd- und Rüstkammer ve Vídni (Leitner 1866-1870, tab. 2: 5, 8; Gamber 1961, 26-27, obr. 18; Thomas, Gamber 1976, 76, A 89 W). Pasovský vlk s kombinací s biskupskou berlou je evidován také 
z meče, považovaného za zbraň Albrechta II. Habsburského, který pochází z 1. poloviny 15. století (Binder 1936, 25, obr. 4; Głosek 1984, 72, kat. č. 120). Obdobně značený meč známe i ze sbírek někdejší alexandrijské zbrojnice (Alexander 1987, 23, kat. č. 80) a několik exemplářo̊ je chováno také ve sbírkách drážd’anské zbrojnice (např. Ehrenthal 1897, 7-8).

7. Byṫ těmito polotovary mohl nepochybně disponovat i výrobce vlastní čepele, zdá se nám pravděpodobnější výše naznačený model, při kterém se počítá s osazením importované čepele a konečnou kompletací zbraně až v místě jejího určení.

8. Würzburští biskupové používali meč jako jeden ze symbolů své moci nejpozději od přelomu 11. a 12. století, kdy jsou na jimi ražených mincích velmi často zobrazováni s mečem v jedné ruce a pastorálem ve druhé. Ve druhé polovině 15. století byl pro würzburské biskupství dokonce biskupem Grumbachem objednán speciální ceremoniální meč. Tato luxusní zbraň s hlavicí vyrobenou z karneolu má čepel signovanou značkami v podobě vlka, takže její původ lze hledat nejspíše také v Pasově (srov. Huther 2007, 95). V průběhu 13. až 15. století byli würzburští biskupové na svých sepulkrálních památkách také velmi často zobrazováni s meči (např. Bauch 1976, 268, obr. 395). To je ostatně i případ krásného figurálního náhrobku biskupa Gerharda, kde je tento prelát realisticky zobrazen s bohatě zdobeným pastorálem, zcela shodným s tím, který byl součástí jeho hrobové výbavy, a dlouhým mečem vybaveným masivní oktogonální hlavicí (obr. 15). Zobrazený meč je však, na rozdíl od biskupské berly, zcela odlišného typu než dochovaná zbraň. Bez zajímavosti však není, že zobrazená pochva na náhrobku je zcela analogicky omotána opaskem, jako na vlastním meči z biskupovy hrobové výbavy. Vlastní meč však představuje poměrně běžný, málo reprezentativní výrobek, který nebyl nijak zvlášt zdoben, a to ani v oblasti pochvy. Zřejmě tak byla do biskupova hrobu uložena jeho osobní zbraň, s jejíž pomocí Gerhard ze Schwarzburgu necelý rok před svou smrtí porazil své nepřátele v krvavé bitvě u Bergtheimu (např. Schulze 1975; Lenssen et al. 2002, 61-62; Schneider 2004, 180-181, kat. č. 53).

\section{Literatura}

Aleksić, M. 2007: Medieval Swords from Southeastern Europe. Material from 12th to 15th Century. Belgrade: Dedra.

Alexander, D. G. 1985: European Swords in the Collections of Istanbul. Part I. Swords from the Arsenal of Alexandria. Waffen- und Kostümkunde 27, 81-118.

Alexander, D. G. 1987: European Swords in the Collections of Istanbul. Part II. Waffen- und Kostümkunde 29, 21-48.

Rudolph Lepke‘s 1904: Waffen- und Kunstsammlung Karl Gimbel: Baden-Baden. Berlin: Rudolph Lepke's Kunst-Auctions-Haus.

Bartlová, M. 2001: Poctivé obrazy. Deskové malírství v Čechách a na Moravě 1400-1460. Praha: Argo.

Bauch, K. 1976: Das mittelalterliche Grabbild. Figürliche Grabmäler des 11. bis 15. Jahrhunderts in Europa. Berlin, New York: Walter de Gruyter.

Binder, M. J. 1936: Ein Königsschwert im Zeughaus. Zeitschrift für historische Waffen- und Kostümkunde XIV, Neue Folge 5, 25-26.

Blair, C. 1958: European Armour circa 1066 to circa 1700. London: B. T. Batsford Ltd.

Bocheński, Z. 1937: Krakowski cech mieczników. Kraków: Biblioteka Krakowska.

Cabalska, M., Mazur, W. 1982: Średniowieczne militaria z Polski Południowej w świetle badań metaloznawczych. Studia do dziejów dawnego uzbrojenia i ubioru wojskowego 8, 5-17.
Capwell, T. 2015: Armour of the English Knight 1400-1450. London: Thomas Del Mar Ltd.

Dufty, A. R. 1974: European swords and daggers in the Tower of London. London: Her majesty's stationery office.

Eco, U. 1998: Umění a krása ve středověké estetice. Praha: Argo.

Ehrenthal, M. von 1897: Führer durch das königliche Historische Museum zu Dresden. Dresden: Historische Museum.

Fajt, J. et al. 1997: Magister Theodoricus. Dvorní malír císaře Karla IV. Umělecká výzdoba posvátných prostor hradu Karlštejna. Praha: Národní galerie.

Fajt, J., Boehm, B. D. et al. 2006: Karel IV. Císař z boží milosti. Kultura a umění za vlády Lucemburků 1310-1437. Praha: Academia.

Gamber, O. 1953: Harnischstudien V. Stilgeschichte des Plattenharnisches von den Anfängen bis um 1440. Jahrbuch der Kunsthistorischen Sammlungen in Wien L, Neue Folge XIV, 53-92.

Gamber, O. 1961: Die mittelalterlichen Blankwaffen der Wiener Waffensammlung. Jahrbuch der Kunsthistorischen Sammlungen LVII, Neue Folge XXI, 7-38.

Gamber, O., Beaufort, Ch. 1990: Katalog der Leibrüstkammer II. Teil. Der Zeitraum von 1530-1560. Wien, Busto Arsizio: Kunsthistorische Museum, Bramante editrice.

Glinianowicz, M. 2005: Stan badań nad uzbrojeniem późnośredniowiecznym w Małopolsce. Acta Militaria Mediaevalia I, 143-164.

Głosek, M. 1973a: Próba analizy znaków na mieczach średniowiecznych ze zbiorów polskich pod kątem ich rodzimego pochodzenia. Kwartalnik Historii Kultury Materialnej XXI, 325-334.

Głosek, M. 1973b: Znaki i napisy na mieczach średniowiecznych w Polsce. Wrocław, Warszawa, Kraków, Gdańsk: Wydawnictwo Polskiej Akademii Nauk.

Głosek, M. 1984: Miecze środkowoeuropejskie z X-XV w. Warszawa: Wydawnictwa Geologiczne.

Głosek, M., Kajzer, L., Nadolski, A. 1978: Broń średniowieczna z ziem polskich. Katalog. Łódź: Państwowe Muzeum Archeologiczne w Warszawie.

Głosek, M., Nadolski, A. 1970: Miecze średniowieczne z ziem polskich. Łódź: Zakład Narodowy imienia Ossolińskich.

Gurlitt, C. 1897: Beschreibende Darstellung der älteren Bau- und Kunstdenkmäler des Königreichs Sachsen. Dresden: Meinhold \& Söhne.

Hilt1, G. 1876: Waffen-Sammlung Sr. Königlichen Hoheit des Prinzen Carl von Preußen. Mittelalterliche Abteilung. Berlin: W. Moeser Hofbuchhandlung.

Hoffmeyer, A. B. 1954: Middelalderens tveceggede svcerd I-II. København: Udgivet af Tøjhusmuseet.

Hošek, J., Košta, J., Žákovský, P. 2019: Ninth to mid-sixteenth century swords from the Czech Republic in their European context. Part I. The finds. Prague, Brno: Archeologický ústav AV ČR, Praha, Archeologický ústav AV ČR, Brno, Národní muzeum, Masarykova univerzita.

Hošek, J., Košta, J., Žákovský, P. 2020: Ninth to mid-sixteenth century swords from the Czech Republic in their European context. Part II. Swords of medieval and early renaissance Europe as a technological and archaeological source. Prague, Brno: Archeologický ústav AV ČR, Praha, Archeologický ústav AV ČR, Brno, Národní muzeum, Masarykova univerzita.

Huther, H. 2007: Die Passauer Wolfsklingen. Legende und Wirklichkeit. Passau: Dietmar Klinger Verlag.

Chaloupka, G. 1965: Vývoj osídlení od 11. do konce 18. století. In: V. Nekuda (ed.): Vlastivěda moravská. Vyškovsko. Brno, Vyškov: Musejní spolek v Brně, Okresní vlastivědné muzeum ve Vyškově, 61-71.

Iwańczak, W. 2001: Po stopách rytírských př́iběhů. Rytírský ideál v českém písemnictví 14. století. Praha: Argo. 
Iwańczak, W. 2011: Lidé meče, modlitby a práce. Tři stavy v českém středověkém myšlení. Praha: Argo.

Krajíc, R., Kukla, Z., Nekuda, R. 1997: Středověký meč ze Mstěnic. In: R. Nekuda, J. Unger (eds.): Z pravěku do středověku. Sborník k 70. narozeninám Vladimíra Nekudy. Brno: Muzejní a vlastivědná společnost v Brně, Moravské zemské muzeum, 250-258.

Kühn, U. 1970: Das Richtschwert in Bayern. Waffen- und Kostümkunde 12, 89-126.

Kuppelmayr, R. 1895: Waffen-Sammlung Kuppelmayr. München: Kuppelmayr.

Laking, G. F. 1920a: A record of european armour and arms through seven centuries I. London: G. Bell and sons Ltd.

Laking, G. F. 1920b: A record of european armour and arms through seven centuries II. London: G. Bell and sons Ltd.

Leitner, Q. 1866-1870: Die Waffensammlung des österreichischen Kaiserhauses im K. K. Artillerie-Arsenal-Museum in Wien. Wien: Verlag von H. Martin.

Lenssen, J. et al. 2002: Domschatz Würzbug. Regensburg: Schnell \& Steiner.

Liwoch, R. 2010: Późnośredniowieczne zabytki z Krakowa Rakowic. Materiaty Archeologiczne XXXVIII, 107-126.

Macek, J. 1997: Česká středověká šlechta. Praha: Argo.

Mäder, S. 2013: Beseelte Klingen. Ein kulturhistorischer Blick auf die Griffwaffen im Museum Altes Zeughaus Solothurn. Solothurn: Museum Altes Zeughaus.

Maisel, W. 1961: Sądownictwo miasta Poznania. Poznań: Państwowe Wydawnictwo Naukowe.

Małowiecki, R. 1989: Dwa miecze z Ciechanowa. Zapiski Ciechanowskie 7, 130-140.

Matějček, A. 1950: Česká malba gotická. Deskové malírství 1350-1450. 3. doplněné vydání. Praha: Melantrich.

Měchurová, Z. 1997: Konůvky - zaniklá střredověká ves ve Ždánickém lese. Srovnávací analýza nálezového fondu ze zaniklé středověké vsi Konůvky, kat. Heršpice, okr. Vyškov. Studie Archeologického ústavu AV ČR v Brně XVII(1). Brno: Archeologický ústav AV ČR.

Měřínský, Z. 1997: Ždánicko ve středověku. In: S. Stuchlík, Z. Klanica, Z. Měřínský (eds.): Pravěk a středověk Ždánicka. Brno: Moravský archeologický klub, 59-92.

Müller, H., Kölling, H. 1986: Europäische Hieb-und Stichwaffen aus der Sammlung des Museums für Deutsche Geschichte. 3. Auflage. Berlin: Militärverlag der Deutschen Demokratischen Republik.

Nickel, H. 1974: Ullstein Waffenbuch. Eine kulturhistorische Waffenkunde mit Markenverzeichnis. Frankfurt am Main, Berlin, Wien: Verlag Ullstein GmbH.

Norman, A. V. B., Wilson, G. M. 1983: Treasures from the Tower of London. An exhibition of Arms and Armour. Norwich: Sainsbury Centre for Visual Arts, University of East Anglia.

Novobilský, M. 2008: Obléhání hradu Lopaty. Rekonstrukce obléhání hradu z roku 1432-1433. Plzeň: Západočeské muzeum.

Oakeshott, E. 1964: The Sword in the Age of Chivalry. London, New York: Frederick A. Praeger, Inc.

Plaček, M. 2001: Ilustrovaná encyklopedie moravských hradů, hrádků a tvrzí. Praha: Libri.

Poszler, G. 2006: Kreuzigungsaltar. In: I. Takács, Z. Jékely, S. Papp, G. Poszler (Hrsg.): Sigismundus rex et imperator. Kunst und Kultur zur Zeit Sigismunds von Luxemburg 1387-1437. Ausstellungskatalog. Budapest, Luxemburg: Philipp von Zabern, 580-586.

Ptáčková, J., Unger, J. 1994: Meč z lelekovického hradu. Castellologica bohemica 4, 251-256.

Seitz, H. 1965: Blankwaffen I. Geschichte und Typenentwicklung im europäischen Kulturbereich. Von der prähistorischen Zeit bis zum Ende des 16. Jahrhunderts. Braunschweig: Klinkhardt \& Biermann.

Schmid, W. M. 1920: Passauer Waffenwesen. Zeitschrift für historische Waffenkunde VIII, 317-342.
Schneider, W. 2004: Schwert. In: W. Jahn, J. Schumann, E. Brockhoff (Hrsg.): Edel und Frei. Franken im Mittelalter. Augsburg: Bayerisches Staatsministerium für Wissenschaft, Forschung und Kunst - Haus der Bayerischen Geschichte, 180-181.

Schulze, H. 1975: Die Gräber des Domes in Würzburg. Würzburger Diözesangeschichtsblätter 37/38, 523-539.

Thomas, B., Gamber, O. 1976: Katalog der Leibrüstkammer. I. Teil. Der Zeitraum von 500 bis 1530. Wien: Kunsthistorisches Museum, Verlag Anton Schroll \& Co.

Trzciński, M. 2001: Miecz katowski, pręgierz, szubienica. Zabytki jurysdykcji karnej na Dolnym Śląsku (XIII-XVIII. w.). Wrocław: Uniwersytet Wroclawski.

Uhlemann, R. H. 1982: Die mittelalterlichen Gerichtsschwerter und die späteren Richtschwerter von Passau. In: K. Stüber, H. Wetter (Hrsg.): Blankwaffen. Armi bianche. Edged weapons. Festschrift Hugo Schneider zu seinem 65. Geburtstag. Stäfa, Zürich: Th. Gut \& Co. Verlag, 33-44.

Unger, J. 1992: Dvě nedokončená šlechtická sídla z 13. století na jižní Moravě. Archaeologia historica 17, 245-251.

Unger, J. 1999: Život na lelekovickém hradě ve 14. století. Antropologická sociokulturní studie. Brno: Nakladatelství Georgetown, NAUMA, Masarykova univerzita.

Ward-Perkins, B. 1967: Medieval Catalogue. London Museum. London: Her majesty's stationery office.

Žákovský, P. 2009a: Dlouhé meče ze sbírek muzeí v Chocni a Vysokém Mýtě. Archeologické rozhledy LXI(3), 509-523.

Žákovský, P. 2009b: Hromadný nález nejstarších platnéřských prací z území Moravy (?). Příspěvek k poznání tzv. kombinovaných zbrojí. Archaeologia historica 34, 409-444.

Žákovský, P. 2012: Dlouhé meče se značkami v podobě biskupské berly z moravských sbírek. In: J. Doležel, M. Wihoda (eds.): Mezi raným a vrcholným středověkem. Pavlu Kouřilovi k šedesátým narozeninám prátelé, kolegové a žáci. Brno: Archeologický ústav AV ČR, Brno, 625-643.

Žákovský, P., Cymbalak, T., Hošek, J., Dejmal, M. 2017: Nález pozdně středověkého dlouhého meče z Prahy - Nového Města. Přehled výzkumů 58(2), 141-187.

\section{Summary}

A weapon found in 2019 in the forest complex of Ždánice Forest can be classified as a long-sword (type XVIa, H1, 1b), and can be reliably dated to the turn of the $15^{\text {th }}$ century. Although the weapon comprises individual components that appear relatively abundantly in Europe on their own, we do not find many exact analogies to the sword in question. For instance, among swords from the territory of the Czech Republic, we have found only one topologically identical sword. Nowadays, this is on display in the museum in Přibyslav (Fig. 14; Hošek, Košta, Žákovský 2019, cat. ID No 401).

The studied weapon is very well preserved. Its total length reaches $1150 \mathrm{~mm}$, of which a rather sturdy double-edged blade has a length of $888 \mathrm{~mm}$. The total weight after conservation is $1905 \mathrm{~g}$. Some construction details suggest that this weapon may have been the result of the work of several specialised craftsmen who could have worked completely independent of each other. For example, the openings in the crossguard and pommel do not correspond in their dimensions, in particular in the width, to the real dimensions of the tang (Figs. 5, 10). This could indicate that the hilt was assembled from pre-prepared components which had to be adapted to this particular blade. The type-XVIa blade was on both sides furnished with three marks taking the form of a forked cross, a diagonal consisting of three equilateral crosses, and a bishop's crosier (Fig. 11). While the first two marks can be considered less common, the signature in the form of a bishop's crosier appears frequently and can be connected with the production 
centre in Passau. The pommel of type $H 1$ has edges, which are significantly bevelled or even concave in places. Similarly-shaped pieces belong to the most common types of pommels used for long-swords dated to the mid- $14^{\text {th }}-$ mid- $15^{\text {th }}$-century. The specifically shaped crossguard is classified as type $1 \mathrm{~b}$, as per Oakeshott's typological system supplemented by M. Głosek (Głosek 1984, 39-40, Fig. 4). Apart from the sword from Ždánice Forest, eight other crossguards of this type have been registered on the territory of the Czech Republic so far (Hošek, Košta, Žákovský 2019, cat. ID No 2, 36, 96, 275, 278, 306, 330 and 395). The territorial distribution of these type- $1 b$ crossguards could indicate their origin in the narrower region of Central Europe. The findings made regarding the sword from Ždánice Forest thus support hypotheses about mass production of sword blades, especially in specialised centres, such as Passau, Solingen and Cologne, from where they were distributed to remoter areas (cf. Mäder 2013, 35-36). At the destination, local sword-makers could then fit imported blades with locally preferred types of hilt components. In our case, this would be the fitting of a blade of Passau provenance with a hilt characteristic of the wider area of Central Europe.

The sword from Ždánice Forest can probably be assigned to the category of purely functional and practical weapons. Although such swords could play a certain symbolic role in their time, at the turn of the $15^{\text {th }}$ century the symbolic function of swords was already partially lost, mainly due to their easy access to all classes of society.

Hypothetically, the sword could have had a certain connection with the nearby fortified settlement in the location of Hradisko, also known in the literature as Újezd or Lhota u Ždánic, or with the extinct village of the same name, which probably had a close relationship with this fortified settlement.

Given the presumed date of manufacture around the turn of the $15^{\text {th }}$ century, it cannot be ruled out that the sword may have been lost (in the place it was later discovered) at some point during the feudal strife and domestic wars at the turn of the century, or during the turbulent times of the Hussite wars, when a number of settlements disappeared in this region (cf. Chaloupka 1965, 66-69; Měchurová 1997, 12-15; Měřínský 1997, 68-88).

\section{Kontakty}

Petr Žákovský

Archeologický ústav AV ČR, Brno, v. v. i. Čechyňská 19

CZ-602 00 Brno

zakovsky@arub.cz

\section{Patrick Bárta}

Archeologický ústav AV ČR, Brno, v. v. i.

Čechyňská 19

CZ-602 00 Brno

barta@arub.cz

\section{Jiří Hošek}

Archeologický ústav AV ČR, Praha, v. v. i. Letenská 4

CZ-118 01 Praha 1

hosek@arup.cas.cz

\section{Klára Rybářová}

Muzeum Vyškovska, př́spěvková organizace náměstí Čsl. armády 2

CZ-682 01 Vyškov

rybarova@muzeum-vyskovska.cz 